\title{
Serotonergic and Serotonin-Accumulating Neurons in the Goldfish Retina
}

\author{
Robert E. Marc, Wei-Ley S. Liu, Kenneth Scholz, ${ }^{a}$ and Jay F. Muller \\ Sensory Sciences Center, University of Texas Graduate School of Biomedical Sciences, Houston, Texas
}

\begin{abstract}
Autoradiography of goldfish retinas incubated in micromolar levels of ${ }^{3} \mathrm{H}$-serotonin displayed 3 kinds of labeled somas in the inner nuclear layer: $S 1$ amacrine cells with heavy labeling, large somas, and a sparse distribution $\left(\approx 93 / \mathrm{mm}^{2}\right)$; $S 2$ amacrine cells with moderate labeling, smaller somas, and a denser distribution $\left(\approx 500 / \mathrm{mm}^{2}\right)$; and a subset of bipolar cells with light labeling, small somas, and a very dense distribution $\left(\approx 4000 / \mathrm{mm}^{2}\right)$. Serotonin-like immunoreactivity was observed only in $\mathbf{S 1}$ amacrine cells and their synaptic terminals. Radiolabeled terminals in the inner plexiform layer formed 4 strata that were differentially assigned to the 3 cell types. $S 1$ amacrine cells arborized in sublayers 1 and 5 , received inputs from type a1 bipolar cells and amacrine cells, and made synapses on other amacrine cells, type a1 bipolar cells and unidentified processes. Thus, $\mathbf{S 1}$ amacrine cells seem to receive significant input from "off-center" pathways. S2 amacrine cells arborized in sublayer 3 and made synapses onto amacrine cells. Labeled bipolar cell terminals were exclusively located in sublayer 2 and were identified as type a2 mixed rod-cone bipolar cells. We conclude that the $\mathbf{S} 1$ amacrine cell is truly serotonergic and that radiolabeling of $S 2$ amacrine cells and type a2 bipolar cells is due to cross-specificity for another carrier or processes unrelated to their neurochemical identities. These observations partially reconcile many previous observations on the types, numbers, and synaptologies of teleost retinal neurons identified by different markers for indoleaminergic transmission.
\end{abstract}

Evidence accumulated over the past decade implicates serotonin (5-hydroxytryptamine; 5-HT) as a possible neurotransmitter in the retinas of various teleost fishes. Endogenous $5-\mathrm{HT}$ has been detected biochemically, histochemically, and immunocytochemically. High-performance liquid chromatography (HPLC) has shown the goldfish retina to contain 200-1000 ng/gm wet weight of a substance that cochromatographs with 5-HT (Osborne, 1982; Tornqvist et al., 1983). This is among the higher values reported for vertebrates and is 1-2 orders of magnitude greater than measurements in most mammalian retinas (see Osborne, 1984, for a summary). Direct formaldehyde-induced fluorescence (FIF) of goldfish retinas reveals both green and

\footnotetext{
Received Oct. 6, 1987; revised Jan. 14, 1988; accepted Jan. 22, 1988.

We thank our colleagues, especially Dr. S.C. Massey, for discussions and reading manuscript drafts. This research was supported by PHS Grant EY 02576.

Correspondence should be addressed to Robert E. Marc, University of Texas, Sensory Sciences Center, 6420 Lamar Fleming, Houston, TX 77030.

${ }^{a}$ Department of Physiology, University of Texas Medical School at Houston, Houston, Texas.

b Department of Physiology, University of Utah Medical School, Salt Lake City, Utah.

Copyright (C) 1988 Society for Neuroscience $0270-6474 / 88 / 093427-24 \$ 02.00 / 0$
}

yellow fluorescent cells in the amacrine cell layer, indicative of endogenous populations of catecholaminergic and indoleaminergic neurons, respectively (Negishi et al., 1983). Furthermore, Tornqvist et al. (1983), Osborne (1982), and Teranishi et al. (1987) have shown that certain goldfish amacrine cells possess 5-HT-like immunoreactivity.

In spite of these observations, the numbers, locations, lamination patterns, and connectivities of indole-associated neurons described in several studies differ across or even within species. This seems largely the result of the problems of discriminating true serotonergic neurons from within a larger set of 5-HTaccumulating cells. The first indication of possible indoleaminergic function in goldfish retina was obtained by FIF (Ehinger and Florén, 1976). Certain cells near the amacrine cell layer were noted to possess a distinctive "yellowish" fluorescence characteristic of the semi-beta-carboline fluorophore formed by the condensation of formaldehyde and serotonin. Most such preparations, however, involved preloading retinas with high levels of catechole- or indole-like ligands. Using such protocols, various workers have described goldfish indoleamine-accumulating amacrine cells as small, slightly displaced into the inner nuclear layer (Ehinger and Florén, 1976), much more abundant than dopaminergic interplexiform cells (e.g., Holmgren-Taylor, 1983), and occasionally resembling bipolar cells (see review by Osborne, 1984). Autoradiography of ${ }^{3} \mathrm{H}-5$-HT uptake reveals both amacrine and bipolar cell labeling (Marc, 1982). Both small and large indoleamine-accumulating cells have been observed by FIF and immunocytochemistry in carp (Teranishi et al., 1987). It is unclear which, if any, of these cells is serotonergic. This problem is considerably exacerbated by the reports of multiple morphological classes of 5-HT-accumulating amacrine cells in rabbit (Sandell and Masland, 1986; Vaney, 1986) and cat (Wässle et al., 1987), since mammals are generally noted for a dearth of chromatographically detectable 5-HT (Florén and Hansson, 1980; Osborne, 1984). Turtles have been described as possessing both 5-HT-accumulating and 5-HT-immunoreactive amacrine and bipolar cells (Witkovsky et al., 1984). Furthermore, Weiler and colleagues (Weiler and Schütte, 1985a, b; Weiler and Ammermüller, 1986) report 5-HT immunoreactivity in amacrine, bipolar, and ganglion cells of turtles. The intent of our research was to provide a detailed characterization of the types, numbers, distributions, and possible synaptologies of ${ }^{3} \mathrm{H}-5$-HT-labeled versus 5-HT-immunoreactive neurons in the goldfish retina. Through application of light microscope autoradiography and immunocytochemistry, individually and in concert, we are able to differentiate 3 types of ${ }^{3} \mathrm{H}-5$-HT-labeled neurons: type S1 amacrine cells, S2 amacrine cells, and type a2 bipolar cells (see Ishida et al., 1980). Only S1 amacrine cells display significant 5-HT-like immunoreactivity, and we propose that they are, at this time, the sole elements of the goldfish retina 
that meet sufficient criteria to be termed serotonergic. Furthermore, through electron microscope autoradiography, we have observed synaptic connections similar to those described by Holmgren-Taylor (1983) and can assign 2 different morphological classes of amacrine cell terminals to the 2 different kinds of ${ }^{3} \mathrm{H}-5-\mathrm{HT}$-labeled amacrine cells.

\section{Materials and Methods}

Uptake and autoradiography. Retinas were isolated from light-adapted goldfishes ( $\approx 10 \mathrm{~cm}$ standard length) immediately after cervical transection and pithing. Isolated retinas were then incubated for $10 \mathrm{~min}$ in an oxygenated physiological saline (Marc and Lam, 1981) containing $\approx 3 \mu \mathrm{M}{ }^{3} \mathrm{H}-5$-HT (New England Nuclear, $\approx 30 \mathrm{Ci} / \mathrm{mmol}, 100 \mu \mathrm{Ci} / \mathrm{ml}$ 5-HT). ${ }^{3} \mathrm{H}-5-\mathrm{HT}$ content was checked periodically by thin-layer chromatography to ensure that over $90 \%$ of the radioactivity comigrated with authentic 5-HT. Some experiments were conducted in the presence of $1 \mathrm{~mm}$ ascorbate and/or $100 \mu \mathrm{M}$ pargyline, but no alterations in label patterns were observed, and such additives were not routinely used. The selectivity of ${ }^{3} \mathrm{H}-5-\mathrm{HT}$ uptake was qualitatively assessed by coincubation in $0.1-1.0 \mathrm{~mm}$ nonradioactive $5-\mathrm{HT}$, tryptophan, or melatonin. Retinas destined for horizontal section analysis were mounted photoreceptor-side down on Gelman Metricel $5 \mu \mathrm{m}$ pore size filters for the incubation and processed on the filters. At the end of each incubation, each retina was rinsed in ice-cold saline for $30 \mathrm{sec}$ prior to immersion in a paraformaldehyde/glutaraldehyde-based fixative (Marc et al., 1978). Fixation, dehydration, embedding, and processing for light and electron microscope autoradiography followed the protocols of Marc and Liu (1985). Exposures ranged from 2-5 weeks and 3-5 months for light and electron microscope autoradiography, respectively. Light microscope autoradiographs were developed in Kodak Dektol for 2 min at $16-18^{\circ} \mathrm{C}$, fixed, washed, and stained in borate-buffered toluidine blue. Electron microscope autoradiographs were developed with either Kodak D-19 (chemical development, serpentine grains) or a phenidon-based solution (physical development, polygonal grains; Boutielle, 1976).

Immunocytochemistry. 5-HT-Like immunoreactivity was assessed by the peroxidase-antiperoxidase (PAP) technique (Sternberger et al., 1970) with a rabbit polyclonal antibody directed against 5-HT conjugated to albumin by formaldehyde (Research Plus, Bayonne, $\mathrm{NJ}$ ). We will use the expression 5-HT immunoreactivity as equivalent to the qualified form 5-HT-like immunoreactivity. The specificity of the antibody was assessed by (1) the selective ability of a 5-HT-albumin conjugate or high levels of free 5-HT $(\approx 100 \mu \mathrm{M})$ to block staining (see Bras et al., 1986 ) and (2) the selective recognition of 5-HT-albumin conjugates in dot immunoassays. Albumin-hapten conjugates were synthesized by methods similar to those described in Matute and Streit (1986) for various amino acids. A $0.6 \%$ solution of BSA (fraction V; Sigma) in 0.1 $\mathrm{M}$ phosphate buffer (pH 7.4) was incubated for $15 \mathrm{~min}$ at room temperature with $100 \mu \mathrm{mol}$ paraformaldehyde and $100 \mu \mathrm{mol} 5-\mathrm{HT}$, dopamine, norepinephrine, tyrosine, or tryptophan. Similar conjugates were made using $100 \mu$ mol glutaraldehyde as the linker. The resultant solutions were dialyzed for $48 \mathrm{hr}$ against cold $0.1 \mathrm{M}$ phosphate buffer (pH 7.4) and stored at $-20^{\circ} \mathrm{C}$ in small aliquots. Dot immunoassays were performed by spotting serial dilutions of the conjugates onto nitrocellulose squares (Bio-Rad, Richmond, CA) and drying them at $60^{\circ} \mathrm{C}$ for $30 \mathrm{~min}$. The nitrocellulose squares were then incubated for $1 \mathrm{hr}$ in $3 \%$ goat serum in Tris-phosphate saline (3\% GSTPBS; TPBS $=10 \mathrm{~mm}$ phosphate, $10 \mathrm{~mm}$ Tris, $150 \mathrm{~mm} \mathrm{NaCl}$, and $0.05 \%$ thimerosol, pH 7.4). They were thereafter successively incubated at room temperature in $1: 1000$ anti-5-HT antiserum in 1\% GSTPBS for $15 \mathrm{hr}, 1 \%$ GSTPBS for $2 \mathrm{hr}, 1: 20$ goat anti-rabbit IgG (heavy and light chain specific; Cappel, Malvern, PA) in 1\% GSTPBS for $1 \mathrm{hr}, 1 \%$ GSTPBS for $2 \mathrm{hr}, 1: 50$ rabbit PAP in $1 \%$ GSTPBS for $30 \mathrm{~min}$, and 1\% GSTPBS for $2 \mathrm{hr}$. Antibody binding was visualized with development for $5 \mathrm{~min}$ in $0.1 \mathrm{M}$ phosphate buffer containing $600 \mu \mathrm{g} / \mathrm{ml}$ diaminobenzidine hydrochloride and $5 \mu \mathrm{l} /$ $\mathrm{ml}$ of $3 \% \mathrm{H}_{2} \mathrm{O}_{2}$. The antibody did not recognize any paraformaldehyde conjugate at any dilution except 5-HT linked to albumin. However, there was a weak recognition of glutaraldehyde-linked tryptophan, although not other glutaraldehyde-based conjugates. Thus, all immunocytochemical procedures utilized a primary paraformaldehyde fixation. Within this limited spectrum of possible model antigens and using the same visualization procedures for immunocytochemistry and dot immunoassays, the anti-5-HT antiserum was selective for 5-HT. The selectivity for and sensitivity to formaldehyde-fixed 5-HT-like substances displayed by the antisera we employed matches well with other antisera directed against formaldehyde-linked 5-HT-protein conjugates (Steinbusch et al., 1978; Conzolazione et al., 1982; Bras et al., 1986) and the results of immunocytochemistry in goldfishes using such antisera (Osborne, 1982; Tornqvist et al., 1983).

Isolated retinas were fixed with $4 \%$ paraformaldehyde and $0.05 \%$ glutaraldehyde, $1 \mathrm{mM} \mathrm{Ca}^{2+}$ and $3 \%$ sucrose in $0.1 \mathrm{M}$ phosphate buffer (with or without $1 \mathrm{~mm}$ ascorbic acid; adjusted to $\mathrm{pH} 7.4$ ) for $1 \mathrm{hr}$ at room temperature and overnight at $4{ }^{\circ} \mathrm{C}$ in the same fixative without glutaraldehyde. Some retinas were incubated in ${ }^{3} \mathrm{H}-5-\mathrm{HT}$, as previously described, prior to fixation for immunocytochemistry. Retinas processed for vertical sections were rinsed with ice-cold $3 \%$ sucrose/phosphate buffer (PBS) for $1 \mathrm{hr}$ prior to embedding in 4\% Agarose M (lowtemperature gelling, Calbiochem). Sections $50 \mu \mathrm{m}$ thick were cut on a Vibratome (Oxford) under ice-cold PBS followed by an additional hour in PBS with $25 \mathrm{~mm}$ hydroxylamine. The sections were preincubated in $3 \%$ goat serum, $0.3 \%$ Triton $\mathrm{X}-100$, and $3 \%$ sucrose in PBS $(3 \%$ GSTXPBS). The raw primary antiserum was diluted 1:200-1:2000 in $1 \%$ GSTXPBS and the sections immersed for $16 \mathrm{hr}$ at room temperature on a rotator. All of the immunocytochemical preparations depicted in this report were produced with $1: 1000$ or $1: 2000$ dilutions. Following two $1 \mathrm{hr}$ rinses in 1\% GSTXPBS, the sections were treated with a 1:20 dilution of goat anti-rabbit IgG in 1\% GSTXPBS for $1 \mathrm{hr}$, followed by two more $1 \mathrm{hr}$ rinses. The linked sites were detected with $1: 50$ or $1: 100$ PAP complex in $1 \%$ GSTXPBS for $30 \mathrm{~min}$, followed by a $1 \mathrm{hr}$ wash in $1 \%$ GSTXPBS, a $1 \mathrm{hr}$ wash in the buffer without goat serum, and 30 $\mathrm{min}$ in PBS. The sections were preincubated in $0.1 \mathrm{M}$ phosphate buffer containing $600 \mu \mathrm{g} / \mathrm{ml}$ diaminobenzidine hydrochloride for $10 \mathrm{~min}$, and the reaction was then initiated by the addition of $5 \mu \mathrm{l} / \mathrm{ml}$ of $3 \% \mathrm{H}_{2} \mathrm{O}_{2}$ and carried out for $7 \mathrm{~min}$. The tissues were rinsed in ice-cold phosphate buffer, refixed in $2.5 \%$ glutaraldehyde in PBS overnight at $4{ }^{\circ} \mathrm{C}$, briefly rinsed in phosphate buffer, postfixed in $1 \% \mathrm{OsO}_{4}$ in $0.1 \mathrm{M}$ phosphate buffer, and finally processed for epoxide embedding as described in Uptake and autoradiography. Sections were mounted in 100\% resin on glass slides beneath plastic coverslips and cured overnight. Individual sections were remounted (Stell and Lightfoot, 1975) and cut at $5 \mu \mathrm{m}$ for conventional light microscopy and $3 \mu \mathrm{m}$ for autoradiography.

Retinal whole mounts were processed for immunocytochemistry by a similar procedure, with minor variations. Prior to fixation, isolated retinas were placed photoreceptor-side down on Gelman Metricel $5 \mu \mathrm{m}$ pore size filters. After fixation, the retinas were briefly rinsed in PBS and the vitreous wicked away from each retina by placing it ganglion cell-side down on 100 mesh nylon screen and pressing bibulous paper against the mesh. Several cycles of immersion in buffer and wicking were performed until no more vitreous could be removed. The retinas were then passed through 2 cycles of freezing in Freon 12 slush and thawing at room temperature. The filters were peeled away, stripping off most of the photoreceptors. The remaining immunocytochemical procedures were identical to those used for Vibratome sections, beginning with a rinse in $25 \mathrm{~mm}$ hydroxylamine in PBS.

Analysis. Light microscope autoradiographs were viewed by brightfield microscopy for photography and by dark-field microscopy for scanning densitometry of terminal laminations in the inner plexiform layer. Individual cells were drawn by camera lucida and measurements of diameter made on a graphics tablet.

${ }^{3} \mathrm{H}-5-\mathrm{HT}$-labeled terminals do not form a confluent band in any given sublayer, so they do not posscss much optical density. However, darkfield illumination yields a useful signal since each terminal acts as a light source. Thus, the average laminar location of labeled terminals was evaluated by scanning microreflectometry. Dark-field illumination does not yield true reflectance but is sufficiently linear with grain density to be equivalent for our purposes. The terminal distribution was measured as previously described (Marc and Liu, 1985; Marc, 1986) with a $0.25 \times 100 \mu \mathrm{m}$ slit and scanned in 0.25 or $0.5 \mu \mathrm{m}$ steps through the inner plexiform layer. Normalized reflectance was then displayed as a function of position in the inner plexiform layer with a resolution of 1 $1.4 \%(100 \times$ step size/scan length).

Counts of cell frequency were made from whole-mount immunocytochemistry preparations or $2-\mu \mathrm{m}$-thick horizonal section autoradiographs. Measurements of cell diameter were made from camera lucida drawings of immunostaincd wholc mounts or ${ }^{3} \mathrm{H}-5-\mathrm{HT}$-labeled cells in vertical sections of immunocytochemical preparations. The former gives a good estimate of the diameter of Sl amacrine cells (uncorrected for $\approx 10-12 \%$ shrinkage), and the latter provides a relative measure of $S 1$ and $\mathrm{S} 2$ amacrine cell diameters, though the true diameters are slightly 

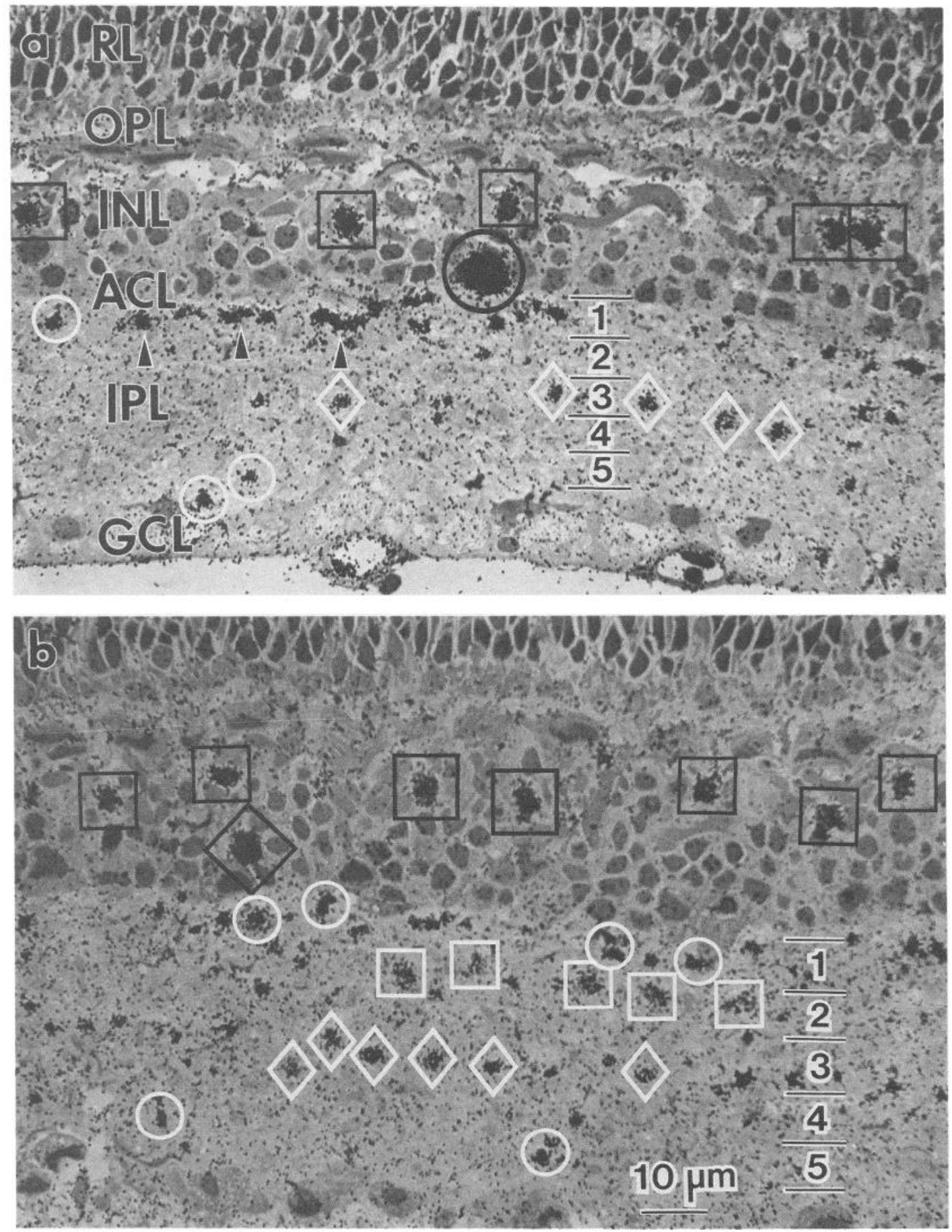

Figure 1. Light microscope autoradiography of ${ }^{3} \mathrm{H}-5$-HT-labeled cells in the goldfish retina; $0.5 \mu \mathrm{m}$ section, 5 week exposure. $a$, Type S1 amacrine cell (black circle) labeled to near saturation is located directly in the amacrine cell layer $(A C L)$ and densely labeled processes (arrowheads) appear to be associated with it. Smaller cell bodies of the numerous labeled bipolar cells (black squares) are located in the inner nuclear layer (INL). Approximate borders of sublayers $1-5$ are indicated in the inner plexiform layer. $R L$, receptor cell layer; $O P L$, outer plexiform layer; $G C L$, ganglion cell layer. $b$, Another section displays labeled bipolar cells and a second class of labeled amacrine cell, type S2 (black diamond). S2 cells are smaller than S1 cells and are often displaced to a row of cells just distal to the amacrine cell layer. Several classes of terminals form 4 strata in the inner plexiform layer. Dense, irregularly shaped profiles (white circles) are abundant in sublayer 1 and infrequent in sublayer 5 . Larger, lightly labeled pufflike structures (white squares) are confined to sublayer 2. Moderately labeled, round terminals of uniform size appear in sublayer 3 (white diamonds).

overestimated due to blurring of cell borders by the overlying silver grains. Drawings of immunoreactive S1 amacrine cell distributions in whole mounts were made with a $25 \times$ planapochromatic objective and a $10 \times$ eyepiece. Overlapping patches of cells were drawn and the pieces fitted together to recreate the final retinal distribution. Distributions of dendritic terminals in the inner plexiform layer were counted in both immunocytochemical and autoradiographic specimens. In whole mounts, sublayers were carefully selected by through-focus of the inner plexiform layer. Horizontal sections were used for autoradiographic counting and any thick clump of grains was counted as a terminal. This provides an 


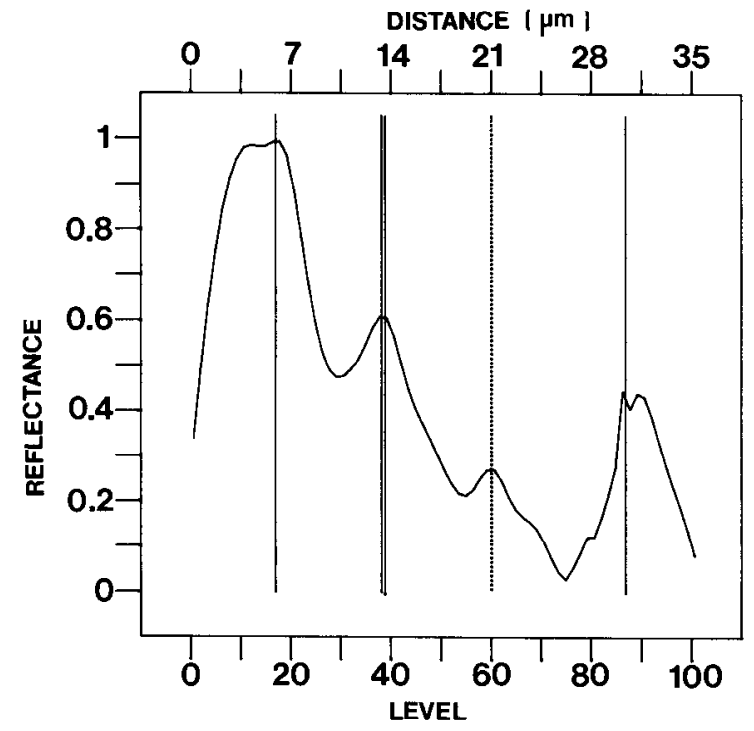

Figure 2. Microreflectance scan of the inner plexiform layer in a ${ }^{3} \mathrm{H}-$ 5 -HT-labeled goldfish retina. A slit $(0.25 \times 100 \mu \mathrm{III})$ was positioned at and with its long axis parallel to the amacrine cell layer/inner plexiform layer border and stepped in $0.25 \mu \mathrm{m}$ increments to the inner plexiform layer/ganglion cell layer border. At each location, the reflectance signal was recorded from a dark-field illuminated, $0.5-\mu \mathrm{m}$-thick autoradiograph. The signal was smoothed with a $1 \mu \mathrm{m}$ half-width Gaussian filter and normalized. Four major peaks are evident at L17 (sublayer 1), L38 (proximal sublayer 2), L60 (sublayer 3/4 border), and L87 (sublayer 5). They correspond to the mean positions of strata of terminals described in Figure 1. The peak heights approximate the product of frequency and mean terminal reflectance.

inaccurate measure of absolute terminal density since some nonvaricose elements such as cross-sectioned proximal dendrites will contaminate the counts, but their frequency will be at least an order of magnitude lower than the true terminal counts (see Results). In heavily labeled autoradiographs, neighboring grain clusters often seemed confluent, and the observer was required to estimate the number of involved varicosities based on the apparent size observed in immunocytochemical preparations.

\section{Results}

\section{Differentiation of cell types}

Fourteen incubations in $\approx 3 \mu \mathrm{M}$ 'II-5-IIT were performed on the retinas of light-adapted goldfishes. Light microscope autoradiography readily displayed the complexity of identifying putative serotonergic neurons, but by controlling exposure time it was possible to differentiate 1, 2, or 3 classes of cells displaying radiolabel. One to two week exposures displayed a single population of cells in the amacrine cell layer. At 3 weeks and beyond, a second class of cells in the amacrine cell layer was visible, along with light labeling in middle to distal inner nuclear layer. At the longest exposure times ( 5 weeks), labeling in many of the cells reached autoradiographic saturation, and a variety of somas and terminals could be discriminated. The cells displaying the heaviest label were located in the amacrine cell layer (Fig. 1a). We call these cells $S 1$ amacrine cells, and they are distinguished by robust labeling, large size $(\approx 8.0 \mu \mathrm{m})$, and the presence of heavily labeled dendrites in sublayer 1 which appear to emanate from the proximal or latcral aspects of the soma. Since most of our light microscope autoradiography is done with serial $0.5 \mu \mathrm{m}$ sections, it was easy to discriminate $\mathrm{S} 1$ cells from a second class of cells we call $S 2$ amacrine cells (Fig. 1b). $\mathrm{S} 2$ amacrine cells have slightly smaller somas $(\approx 6 \mu \mathrm{m})$ and moderate uptake relative to $\mathrm{S} 1$ amacrine cells, and they are often displaced one cell layer distal to the amacrine cell layer. In addition to these cells, the inner nuclear layer is well endowed with small $(\approx 5 \mu \mathrm{m})$, slightly prolate, ${ }^{3} \mathrm{H}-5-\mathrm{HT}$-labeled profiles that resemble bipolar cells (Fig. 1); they are the least efficient at accumulating ${ }^{3} \mathrm{H}-5-\mathrm{HT}$. The selectivity of all these cell types for ${ }^{3} \mathrm{H}-5-\mathrm{HT}$ was potent, and virtually all labeling was abolished by co-incubation in unlabeled $1.0 \mathrm{~mm} 5-\mathrm{HT}$. Similar levels of tryptophan had no detectable effect on labeling; $100 \mu \mathrm{m}$ melatonin depressed diffuse background labeling slightly but had no effect on the types of cells labeled.

The inner plexiform layer also exhibited some heterogeneity in labeled structures, seen best in Fig. $1 b$ due to a fortuitous alignment of elements. Within sublayer 1 , ropelike labeled dendrites are typically located near S1 amacrine cells, whereas punctate, densely labeled terminals are irregularly distributed throughout sublayer 1 , often in the proximal half. Sublayer 2 contains a fairly uniform distribution of lightly labeled, pufflike terminals. They are clearly different from those in sublayer 1 , and we will show that they are, in fact, the axon terminal swellings of a subset of bipolar cells. A third stratum of labeled terminals appears in the proximal half of sublayer 3 , and often at the sublayer 3-4 border. These appear rounded, of uniform size and slightly more labeled than those in sublayer 2 . Finally, a sparse stratum of heavily labeled, irregularly shaped terminals occurs in the middle of sublayer 5 . The average laminar location of these different terminals is summarized by the microreflectance scan of Figure 2. A slightly oblique section through the inner plexiform layer provided good separation of the layers, and peaks of reflectance were recorded at $\mathrm{L} 17, \mathrm{~L} 38, \mathrm{~L} 60$, and L87, corresponding to the visual laminar assignments just summarized. The peak heights cannot accurately reflect frequency of terminals since each kind of terminal has a different label density, but their unique positions imply that a substructure cxists within sublaycrs and that the biological sublayers may have different dimensions than 5 equal bands conventionally used to denote lamination.

The 3 classes of ${ }^{3} \mathrm{H}-5-\mathrm{HT}$-labeled cells may also be viewed in oblique or horizontal sections to reveal something about their distributions. Serial $2 \mu \mathrm{m}$ sections taken from flat-mounted, radiolabeled retinas were exposed for 5 weeks. Sections through the inner nuclear layer display a roughly uniform array of labeled bipolar cells (Fig. 3a). The frequency of labeled bipolar cells in this sample was $4096 / \mathrm{mm}^{2}$, much higher than previously noted for any single class of bipolar cell (Marc, 1982). It is difficult to section in a plane that adequately displays both S1 and S2 amacrine cells since they are slightly displaced from each other. Figure $3 b$ is an oblique section that passes through the amacrine cell layer at a shallow angle and is contiguous with the inner plexiform layer at the left and the inner nuclear layer, above and below, forming a saddle-shaped sample of the amacrine cell layer. Contained therein are two S1 and five S2 somas, displaying their characteristic differences in diameter. In 7 samples of the amacrine cell layer, we determined an $\mathrm{S} 2: \mathrm{S} 1$ amacrine cell ratio of $5.5 \pm 2$. This result is significant for interpreting cell encounter frequencies reported for FIF procedures (see Discussion).

In contrast to the 3 cell types labeled by uptake, we found only a single amacrine cell type to be immunoreactive using 1:1000-1:2000 dilutions of anti-5-HT serum. Typical immunoreactive cells had large somas located in the amacrine cell layer and exhibited smooth, moderately thick primary dendrites 

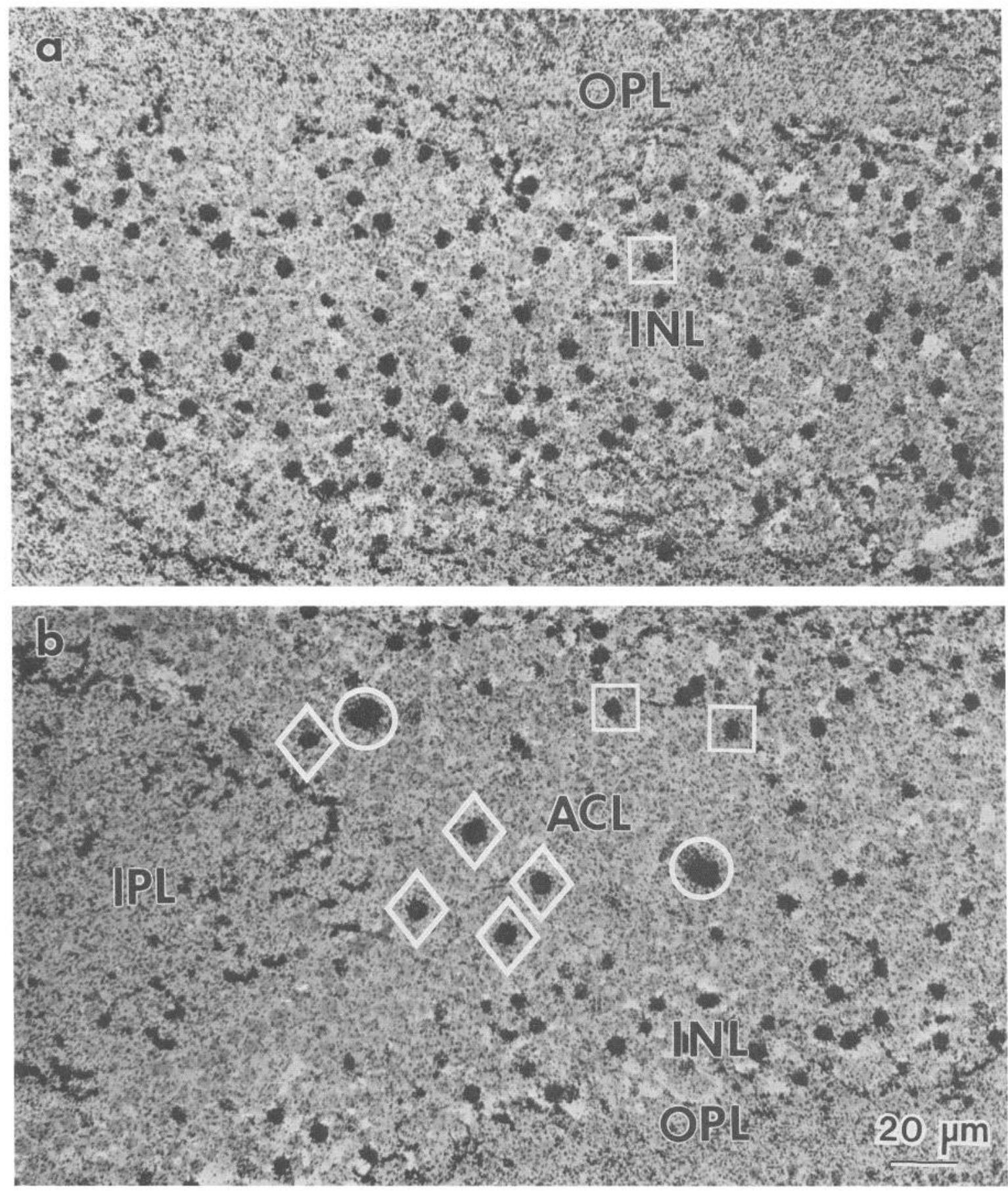

Figure 3. Light microscope autoradiography of near-horizontal $2 \mu \mathrm{m}$ sections of ${ }^{3} \mathrm{H}-5-\mathrm{HT}$-labeled goldfish retina. $a$, High frequency of labeled bipolar cells is apparent in a section through the inner nuclear layer, and the outer plexiform layer displays irregular streaks of labeling that represent their dendrites. $b$, Oblique section through the inner retina revealing all 3 size classes of labeled cells. S1 amacrine cells are indicated by circles, S2 amacrine cells by diamonds, and 2 labeled bipolar cells by squares.

that radiated and branched in sublayer 1 (Fig. 4), similar to type $\mathrm{S} 1$ amacrine cells identified by ${ }^{3} \mathrm{H}-5-\mathrm{HT}$-labeling. The dendrites in sublayer 1 quickly thinned to $<0.2 \mu \mathrm{m}$ in diameter and were decorated with 0.5 - to $2-\mu \mathrm{m}$-diameter varicosities or "terminals." Immunoreactive processes interconnected the terminal arbors in sublayers 1 and 5, the incidence of varicosities being significantly less in sublayer 5 . This terminal distribution resembled that of the heavily ${ }^{3} \mathrm{H}-5$-HT-labeled terminals in sublayers 1 and 5 . To test the hypothesis that $\mathrm{S} 1$ amacrine cells and the immunoreactive cells were the same population, we performed immunocytochemistry on ${ }^{3} \mathrm{H}-5$-HT-labeled retinas. It is important to note that these brief incubations in $3 \mu \mathrm{M}$ 5-HT do not lead to any changes in the number of 5-HT-immunoreactive cells. Fifty individual immunoreactive cells were resectioned for autoradiography and all exhibited robust ${ }^{3} \mathrm{H}-5-$ HT labeling (Fig. 5). Short exposures were necessary to prevent the silver grains from obscuring the immunoreactivity and, at these exposures, no other labeled cells were detectable. At long 


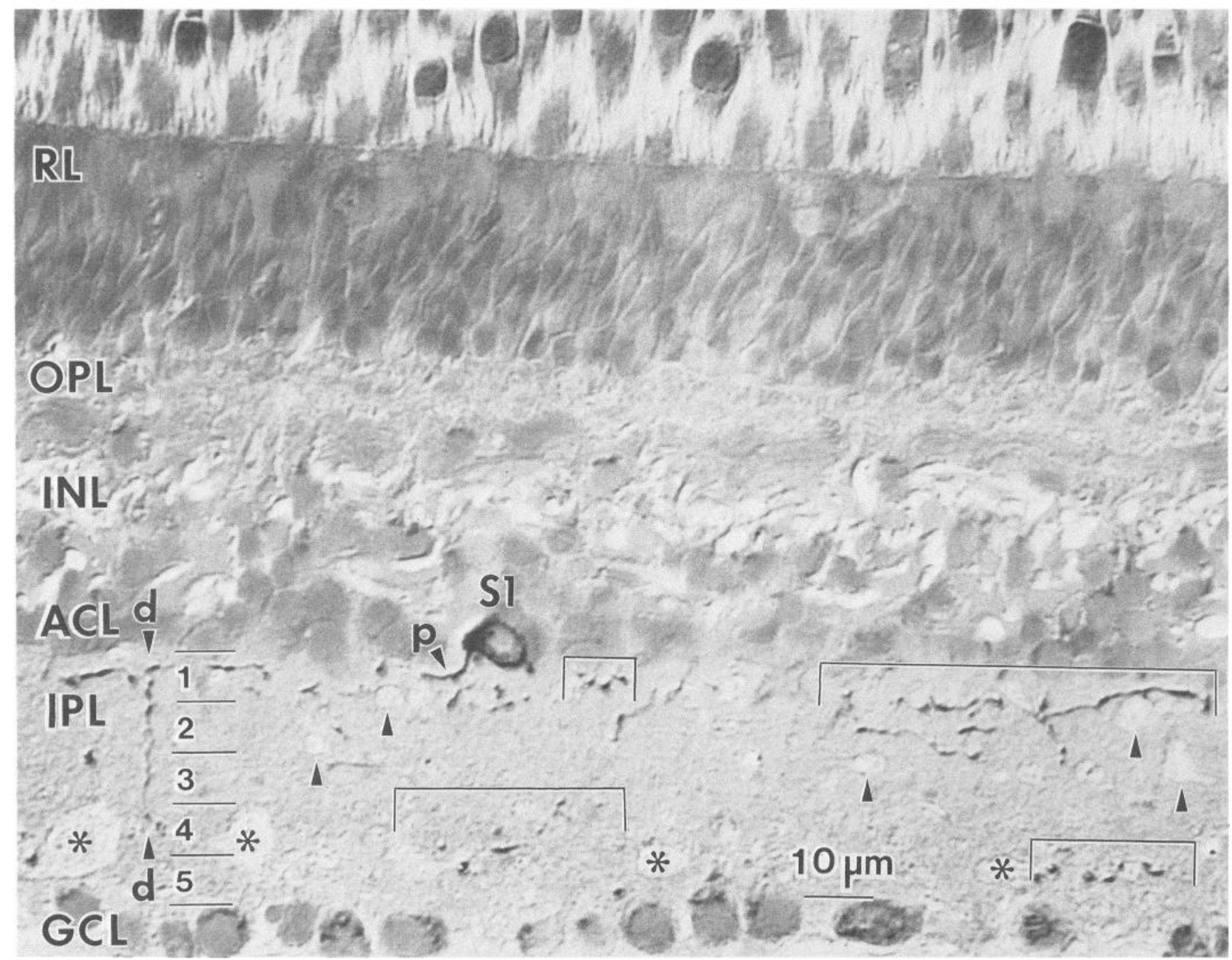

Figure 4. Serotonin-like immunoreactivity in the goldfish retina; $5-\mu \mathrm{m}$-thick section prepared from a plastic-embedded $50 \mu \mathrm{m}$ Vibratome section, counterstained with toluidine blue and viewed by Nomarski differential interference contrast. A single S1-like soma is indicated. Such cells possess 1 or 2 smooth primary dendrites $(p)$ that descend to sublayer 1 and run laterally. These dendrites also send single descending processes $(d)$ into the proximal inner plexiform layer, where they begin to branch again to form a second sparse plexus in sublayer 5 . Clusters of terminals in sublayers 1 and 5 are indicated by box brackets. Arrowheads, unlabeled bipolar cell terminals in distal inner plexiform layer; asterisks, unlabeled type b bipolar cells in proximal inner plexiform layer.

exposures, which completely obscure immunoreactivity, abundant radiolabeled, nonimmunoreactive cells (not shown) appear in the inner nuclear layer next to the amacrine cell layer (S2 amacrine cells) and amongst the bipolar cells. The immunoreactive and nonimmunoreactive amacrine cells labeled by uptake clearly form 2 size populations assignable to type $\mathrm{S} 1$ and S2 amacrine cells (Fig. 6). ${ }^{3} \mathrm{H}-5-\mathrm{HT}$-labeled cells in or next to the amacrine cell layer of the immunostained sections were drawn by camera lucida and their maximum diameters measured on a graphics tablet. The smaller population of immunoreactive $\mathrm{S} 1$ amacrine cells is composed of the larger cells (mean $=8.0 \pm 1.2 \mu \mathrm{m}, n=58$ ) whereas the larger nonimmunoreactive S2 amacrine cell population possessed modestly sized cells $($ mean $=5.7 \pm 1.0 \mu \mathrm{m}, n=197)$. They are clearly separate populations, and there is no evidence to support further subdivision of either group. The smallest somas in the inner nuclear layer (mean $=5.4 \pm 0.5 \mu \mathrm{m}, n=92$ ) resemble bipolar cells and contribute dendrites to the outer plexiform layer. Electron microscope autoradiography confirms the abundance of ${ }^{3} \mathrm{H}-5-\mathrm{HT}$ - labeled bipolar cell synaptic terminals in sublayer 2 (see Electron microscope autoradiography). Thus, we conclude that ${ }^{3} \mathrm{H}-5-\mathrm{HT}$ labeled bipolar cells form a unique subset of the bipolar cell population.

We recognized the possibility that different levels of endogenous 5-HT may be expressed by the 3 classes of cells, and this might account for the labeling discordance. Thus, we examined immunocytochemical labeling patterns observed over a range of antiserum dilutions: 1:2000, 1:1000, 1:500, and 1:200. In no case did any selective, additional dendritic or synaptic terminal labeling appear in the inner plexiform layer. At a 1:200 dilution, all cells began to display a uniform, pale brown somatic labeling, perhaps due to weak cross-reactivity with glutaraldehyde-fixed tryptophan residues. S2 amacrine cells never became selectively labeled. At a 1:500 dilution, we observed a faint but selective labeling of bipolar cells that was exclusively somatic, undetectable at high dilutions (1:1000), and masked by the uniform staining at low dilutions (1:200). At no dilution did any 5-HTimmunoreactive bipolar cell terminals appear in the inner plex- 

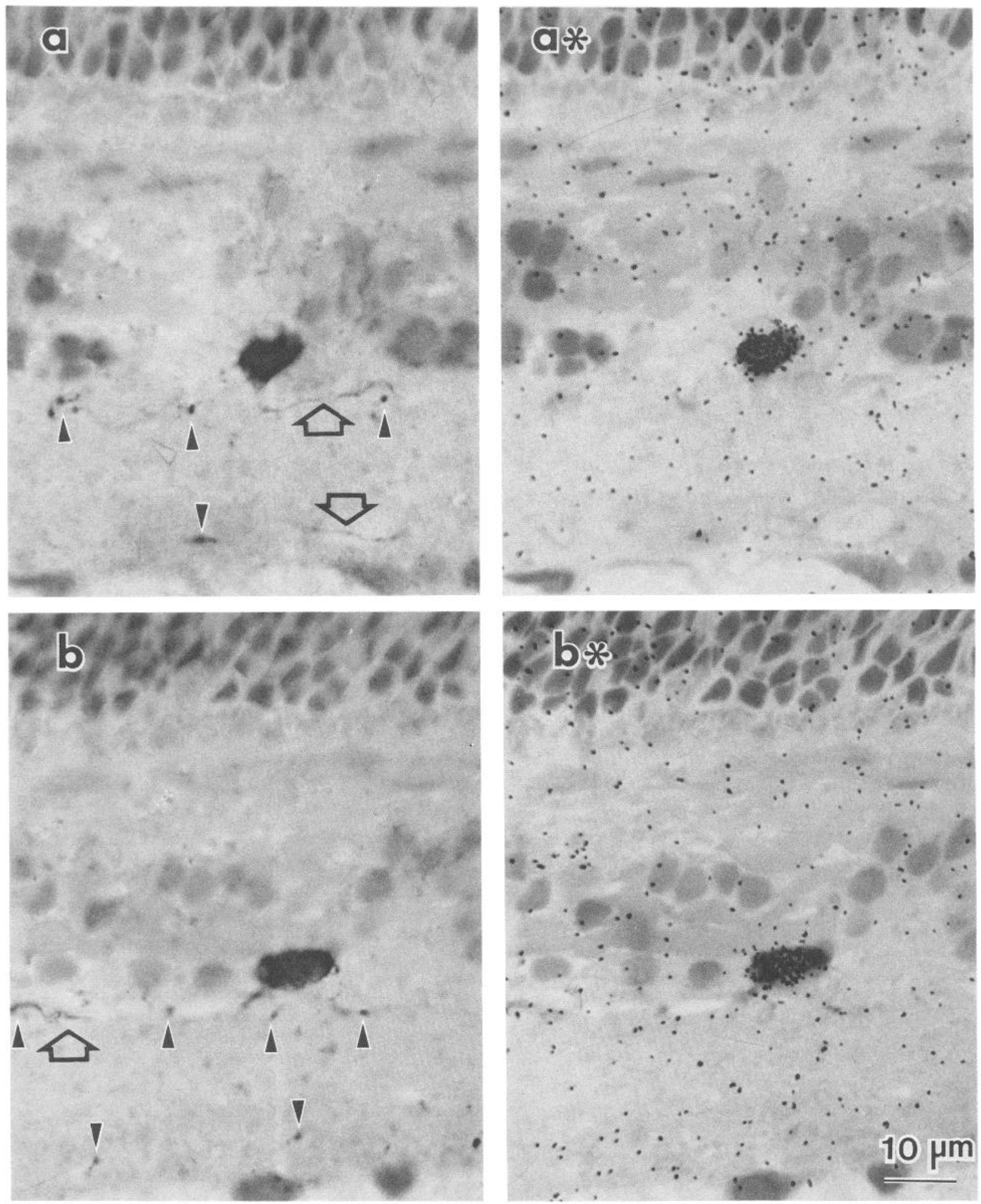

Figure 5. Combined immunocytochemistry/autoradiography of ${ }^{3} \mathrm{H}-5$-HT-incubated goldfish retina. Tissue processed as described in Materials and Methods. a, Immunoreactive S1 amacrine cell; immunoreactive processes (open arrows) and varicosities (arrowheads) are distributed in sublayers 1 and 5. $a^{*}$, Same section with focus on the emulsion showing heavy radiolabeling exclusively over the S1 amacrine cell. $b$, Second immunoreactive $\mathrm{S} 1$ amacrine cell with strongly immunoreactive primary dendrites, assorted processes, and varicosities in sublayers 1 and 5 . $b^{*}$, Focus on the emulsion layer showing strong preferential radiolabeling of the $\mathrm{S} 1$ amacrine cell ( $3 \mu \mathrm{m}$ section, 3 week exposure).

iform layer. The weak bipolar cell labeling was observed only in flat mounts where sufficient optical path length through the absorbing reaction product was achieved, and the patterning and frequency were identical to those of ${ }^{3} \mathrm{H}-5-\mathrm{HT}$-labeled bi- polar cells. If this immunoreactivity is the consequence of 5-HT content, it is not synaptic, and we suspect that it derives from an indirect "loading" of the bipolar cells from another source (see Discussion). 


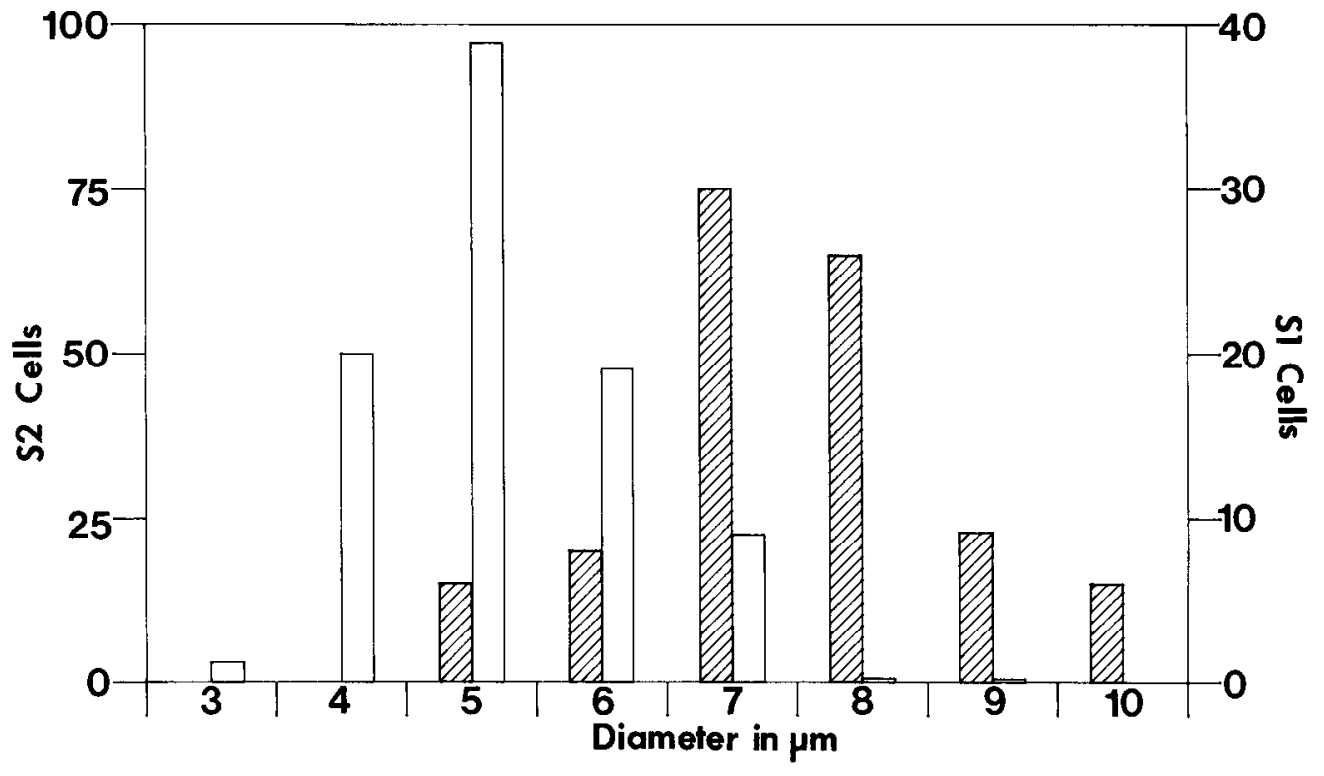

Figure 6. Histogram of the number of radiolabeled amacrine cells versus diameter in combined immunocytochemistry and autoradiography of ${ }^{3} \mathrm{H}$ 5-HT-labeled goldfish retina. Open bars, ${ }^{3} \mathrm{H}-5$-HT-labeled, nonimmunoreactive S2 cells; hatched bars, double-labeled $\mathrm{S} 1$ amacrine cells.

\section{Spatial organization of $S 1$ amacrine cells}

Successful whole-mount immunostaining was achieved in 4 goldfish retinas. All S1 amacrinc cells appcarcd to be stained. For photographic purposes, one whole-mounted retina was sectioned horizontally at $5 \mu \mathrm{m}$ and viewed by Nomarski differential interference contrast (Fig. 7). The selectivity of the anti-5-HT serum for certain cells is dramatic. A similar distribution of S1 cells was obtained by carefully sectioning ${ }^{3} \mathrm{H}-5-\mathrm{HT}$-labeled, flatmounted retinas at $2 \mu \mathrm{m}$ and montaging the photomicrographs of 2 week exposure autoradiographs (Fig. 8). This selectively reveals the amacrine cells with the most robust ${ }^{3} \mathrm{H}-5-\mathrm{HT}$ labeling. The cell frequency in both cases was between $80-100$ cells $/ \mathrm{mm}^{2}$. The distribution of 2171 immunoreactive S1 amacrine cells for one retina is shown in Figure 9. The organization of the cells is not well patterned but is clearly nonrandom, with a mean cell frequency of $93 \pm 13$ cells $/ \mathrm{mm}^{2}$. The patterning of 120 patches of retina was compared with that predicted by the Poisson distribution and was found to be nonrandom but not well ordered $(D=0.15, n=120, p \leq 0.01$, Komolgorov-Smirnov test; Ostle and Mensing, 1975). Another important observation was the absence of any frequency gradient as a function of retinal eccentricity in all 4 immunocytochemical preparations and 2 horizontal section autoradiographic preparations.

\section{Dendritic patterns of $S I$ and $S 2$ amacrine cells}

In vicw of the quality of the immunostaining and the ability to label $\mathrm{S} 1$ and $\mathrm{S} 2$ amacrine cells reliably by ${ }^{3} \mathrm{H}-5-\mathrm{HT}$ uptake, we sought more detailed descriptions of their dendritic features. S1 amacrine cells possess 1 or 2 smooth primary dendrites $(\approx 0.75-$ $1.0 \mu \mathrm{m}$ diameter) that project either directly from the proximal face of the cell into sublayer 1 or, more often, laterally into the amacrine cell layer where they travel a few tens of micrometers before descending into sublayer 1 (Fig. 10). At very high magnification, additional fine proximal dendrites were noted on the somas of S1 amacrine cells, but they appear not to give rise to major dendritic branches. The primary dendrites branch 2 or 3 times before thinning down to $<0.2 \mu \mathrm{m}$ and displaying varicosities. The quality of the immunostaining was sufficient to permit reconstruction of portions of seven $\mathrm{S} 1$ amacrine cells in whole mounts and trace the connections between the dendritic arbors of sublayers 1 and 5 . 'The sizes of the varicosities along a single process were variable, and there was no obvious relation between size and distance from the soma. In the cells drawn, only partial dendritic arbors were reconstructed, but the processes in sublayer 5 were considerably less branched and less recurving than those in sublayer 1 (i.e., for the cell drawn, the total area encompassed $\div$ total dendritic length $=9 \mu \mathrm{m}^{2}$ retinal area $/ \mu \mathrm{m}$ of dendritic length in sublayer 1 and $15 \mu \mathrm{m}^{2} / \mu \mathrm{m}$ in sublayer 5). The frequencies of varicosities per unit length of dendrite were similar, however: $3.9 \mu \mathrm{m}$ of dendrite per varicosity in sublayer 1 and $4.0 \mu \mathrm{m}$ of dendrite per varicosity in sublayer 2 .

The quantitative distributions of immunoreactive terminals in the inner plexiform layer were determined by manual counting of whole mounts or horizontal-oblique $5 \mu \mathrm{m}$ sections. We counted 4555 terminals in 4 sample areas $\left(2.33 \times 10^{-2} \mathrm{~mm}^{2}\right.$ each) in each of sublayers 1,3 , and 5 . In sublayer 1 , the immunoreactive processes form an irregular lacework (Fig. 12a) with an average of around 31,000 varicosities $/ \mathrm{mm}^{2}$. As onc moves into sublayers $2-4$, the density drops radically, and in sublayer 3 the processes are few, occasionally traveling laterally in the plane of the inner plexiform layer, but most often simply crossing (Fig. 12b), and the apparent frequency drops to a little over $4000 / \mathrm{mm}^{2}$. Finally, the processes increase in number in sublayer 5 (Fig. $12 c$ and bottom of $12 b$ ), forming long, relatively unbranched dendrites displaying about 14,000 varicosities $/ \mathrm{mm}^{2}$.

Similar counts were made from horizontal-oblique $2 \mu \mathrm{m} \mathrm{sec}-$ tion autoradiographs after short and long exposures (Fig. 13) to selectively reveal the terminals of $\mathbf{S} 1$ amacrine cells alone or the terminals of both $\mathbf{S} 1$ and $\mathbf{S} 2$ amacrine cells. Short-exposure autoradiographs were analyzed by counting 4 areas $\left(1.5 \times 10^{-2}\right.$ $\mathrm{mm}^{2}$ each, 929 terminals in all) in each of sublayers 1, 3, and 5. Likewise, 4 areas $\left(9.0 \times 10^{-3}\right.$ to $2.3 \times 10^{-2} \mathrm{~mm}^{2}, 1880$ terminals in all) for each of sublayers 1,3 , and 5 were counted for long-exposure autoradiographs. We corrected the autoradiographic counts for section thickness by determining the true thicknesses of the terminal fields with through-focus of the immunostained preparations and scanning microreflectance peak widths. Assuming that our exposures were long enough to detect 


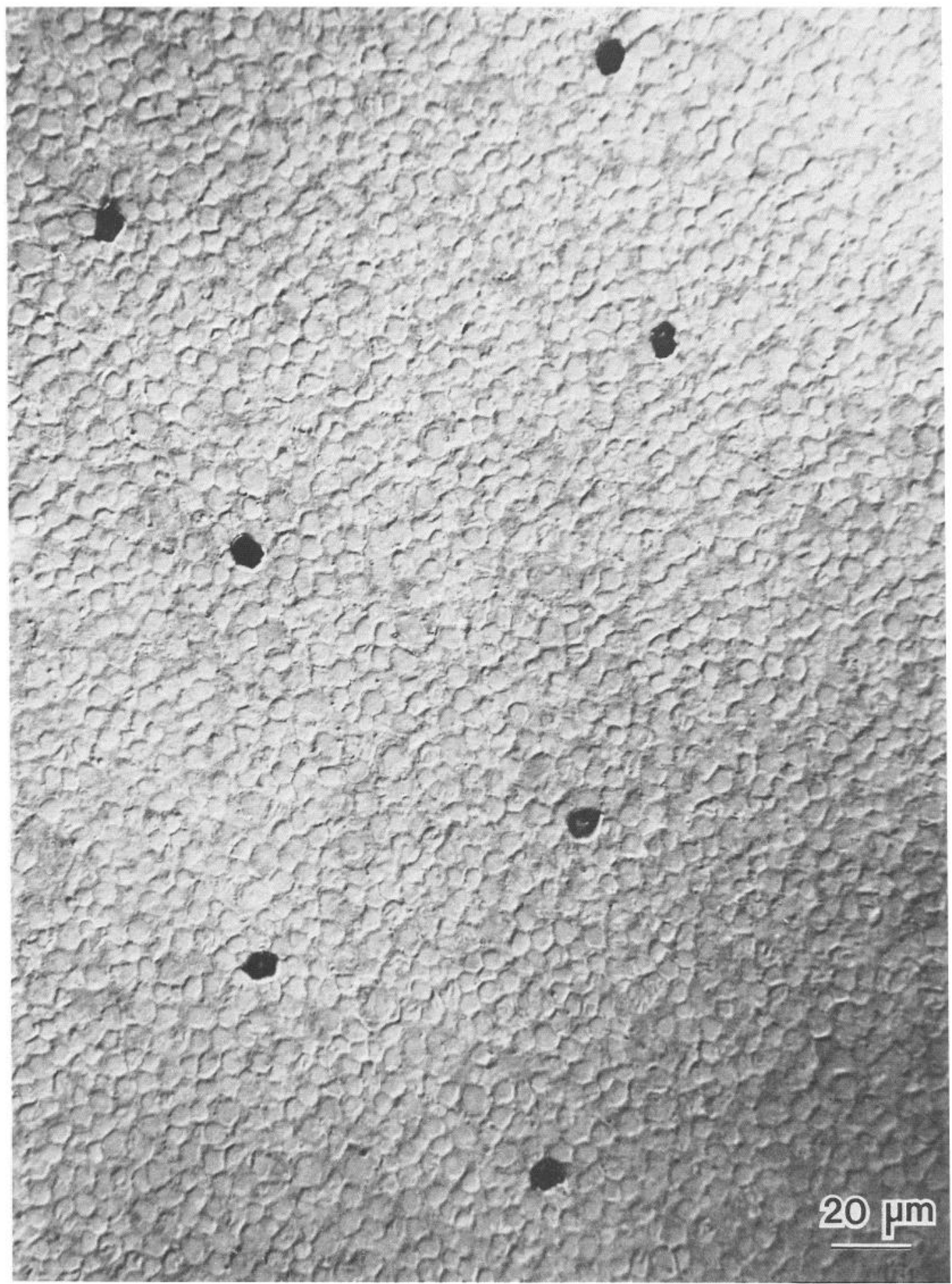

Figure 7. Nomarski differential interference contrast photomicrograph of a $5 \mu \mathrm{m}$ horizontal section through the amacrine cell layer taken from a whole-mount goldfish retina labeled with anti-5-HT immunoglobulins. Individual S1 amacrine cells are sparsely distributed, embedded in a field of nonimmunoreactive somas.

$100 \%$ of the radioactive terminals, the measured frequency $/ \mathrm{mm}^{2}$ in autoradiographs should have been diminished by the ratio of section thickness to actual layer thickness $(2 \mu \mathrm{m} / 5 \mu \mathrm{m}$, or $\approx$ $40 \%$ ). This is clearly an approximation but yields results quite comparable with immunocytochemistry. The data were plotted in histogram form for comparison with immunocytochemical results (Fig. 14). Short-exposure autoradiographs, which preferentially label S1 amacrine cells, displayed a raw mean of 13,821 terminals $/ \mathrm{mm}^{2}$ in sublayer 1 ; after correction, this becomes $33,203 / \mathrm{mm}^{2}$, quite close to the value determined immunocytochemically $\left(30,794 / \mathrm{mm}^{2}\right)$. This gives us confidence that the strategy of counting grain clusters as terminals gives a fairly accurate representation of true numbers of varicosities. Thus, the frequencies of terminals in sublayers 3 and 5 are also similar for immunocytochemistry and short-exposure autoradiography (Fig. 14). The values for long-exposure autoradiographs (S1+S2 
Figure 8. Montage from horizontal sections processed for light microscope autoradiography of ${ }^{3} \mathrm{H}-5-\mathrm{HT}$-labeled goldfish retina ( $2 \mu \mathrm{m}$ sections, 2 week exposure). At this short exposure time, the S1 cells are just below saturation and are the only detectable cells. The S1 cell population has the same size and frequency distribution and patterning as observed in whole-mount immunocytochemistry. Nearly full-diameter cells are indicated by single arrowheads; a fragment of a cell is indicated by a double arrowhead.

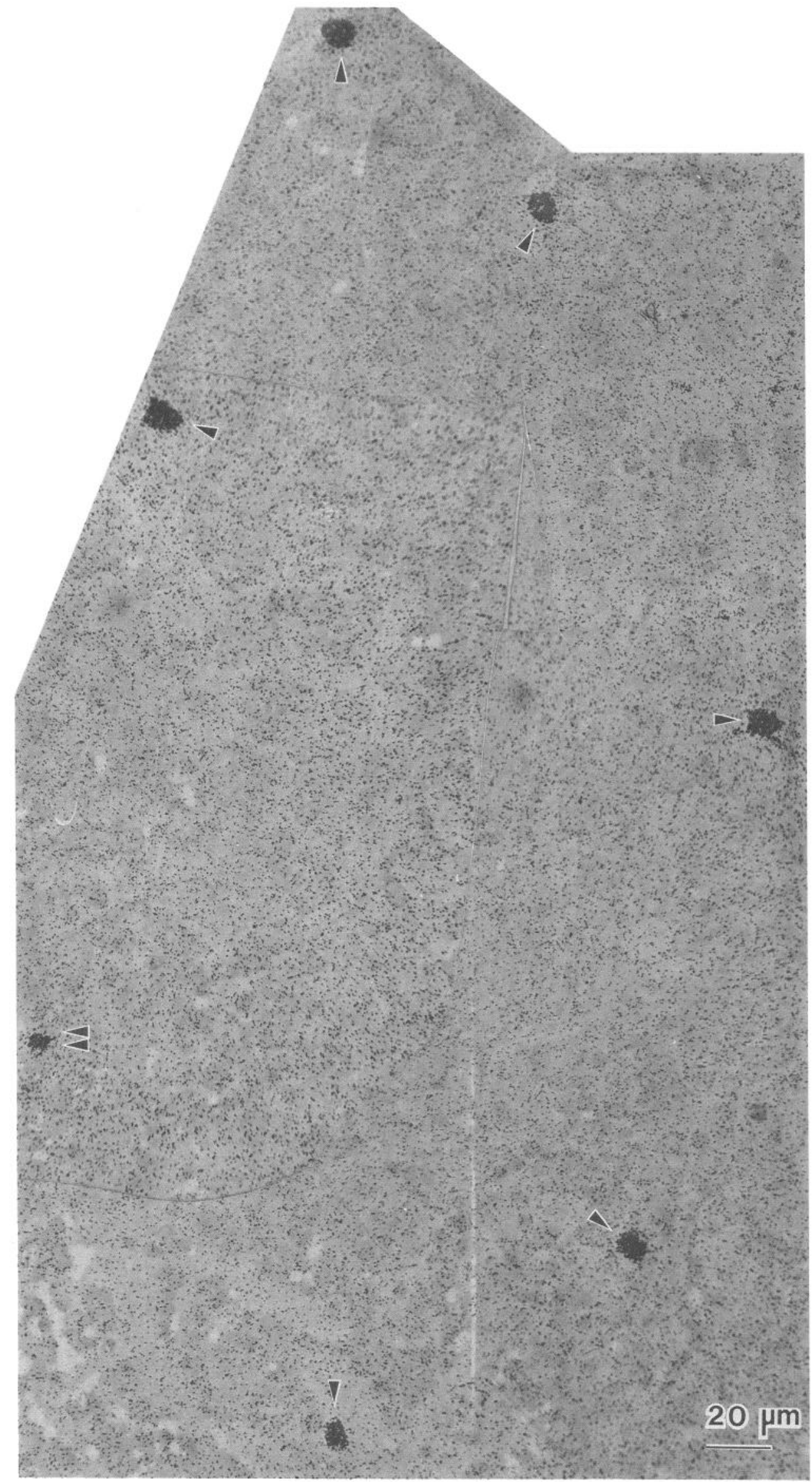




\begin{tabular}{lccc}
\hline Table 1. & Synapse distribution in the inner plexiform layer \\
Sublayer & Ser AC $\rightarrow$ & $\rightarrow$ Ser AC & Ser BC \\
\hline 1 & 9 & 14 & \\
AC & 8 & 15 & 0 \\
BC & 19 & $a$ & \\
?C & 1 & 2 & \\
2 & 0 & 0 & $13^{b}$ \\
AC & 1 & $a$ & \\
BC & 6 & & \\
?C & 0 & 4 & 0 \\
3 & 7 & 0 & \\
AC & & $a$ & \\
BC & 2 & 0 & \\
?C & 0 & 0 & \\
5 & 10 & $a$ & \\
AC & & & \\
BC & ?C & &
\end{tabular}

Ser $\rightarrow$, labeled profile presynaptic. $\rightarrow$ Ser, labeled profile postsynaptic. ?C, Unidentified cell type.

${ }^{a}$ All inputs presumed to be from amacrine or bipolar cells.

${ }^{b}$ Bipolar cell terminals not included in contact total of 98 .

amacrine cells) in sublayers 1 and 5 are slightly higher but not much different from immunocytochemistry or short-exposure autoradiography. However, there are 3-4 times the terminals in sublayer 3 when both $\mathrm{S} 1$ and $\mathrm{S} 2$ amacrine cells are labeled as when $\mathrm{S} 1$ amacrine cell terminals are estimated alone. This difference is significant at $p \leq 0.001$ (Student $t$ test). The increment should be due to the S2 amacrine cells alone, and we calculate their true terminal frequency in sublayer 3 to be $\approx 14,000 / \mathrm{mm}^{2}$. These measures of terminal frequency will be discussed later in the context of estimating the dendritic field sizes of S1 and S2 amacrine cells.

\section{Electron microscope autoradiography}

Given that there are 3 discriminable populations of ${ }^{3} \mathrm{H}-5$-HTlabeled retinal neurons, we wished to evaluate their possible synaptic connections through electron microscope autoradiography. This is particularly useful since there exist prior data with which our findings may be compared (Holmgren-Taylor, 1983). The somas of S1 and S2 amacrine cells are easily discriminated (Fig. 15). S1 amacrine cells are the largest of the ${ }^{3} \mathrm{H}-5-\mathrm{HT}$ labeled cells in the inner nuclear layer and tend to have electronlucent cytoplasm and a nucleus flattened on one side (Fig. 15a). S2 amacrine cells, by comparison, are clearly smaller, more frequently encountered, possess a scanty rim of moderately electron-dense cytoplasm, and generally exhibit oval, symmetrical nuclei (Fig. 15b).

We just demonstrated that most of the labeled terminals in sublayers 1 and 5 probably derive from S1 amacrine cells and that most of the labeled terminals in sublayer 3 will represent S2 amacrine cells. The laminar distributions of different kinds of synaptic contacts observed in this study are summarized in Table 1. The 98 tallied contacts represent the residual of over 2000 labeled profiles, of which only about 200 displayed clear synaptic contacts. The remaining 98 constituted those varicosities containing synapses that were documented according to location in the inner plexiform layer and met our criterion of 3 grains per terminal at a signal-to-noise ratio of about 30:1 (de-

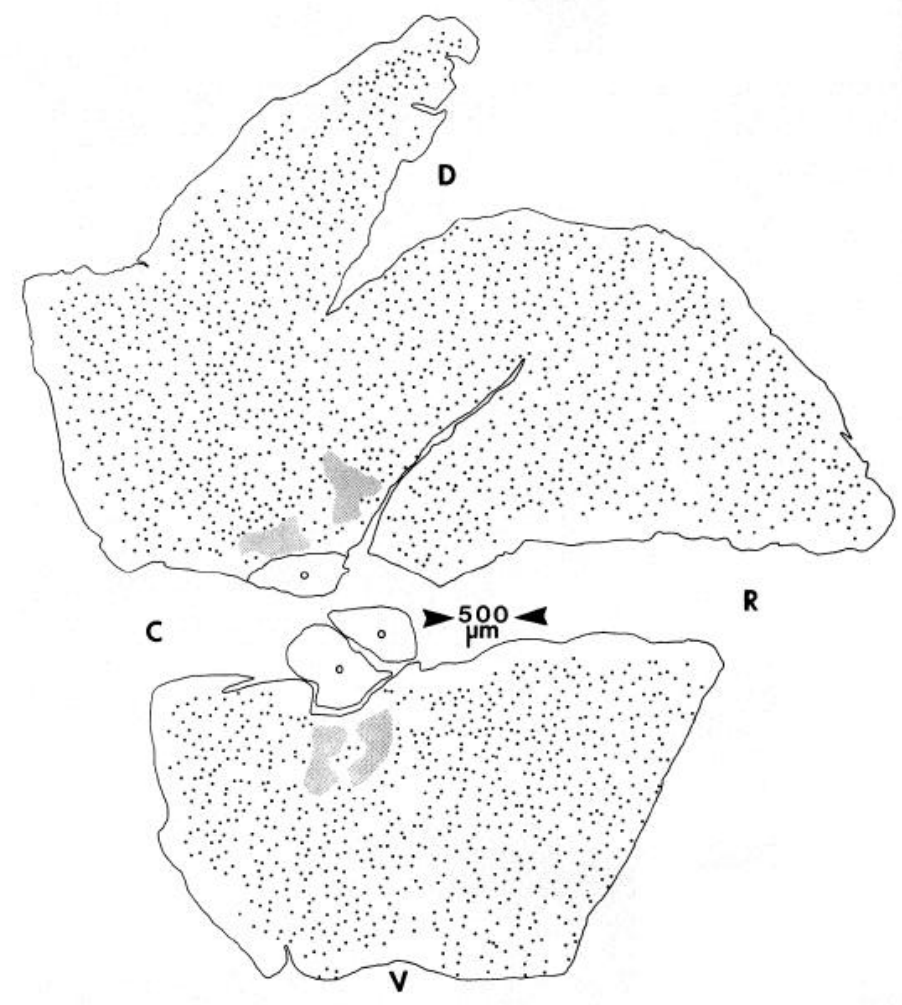

Figure 9. Distribution of $2171 \mathrm{~S} 1$ amacrine cells observed in a wholemount goldfish retina labeled with anti-5-HT immunoglobulins. Stippled regions indicate patches of pigmentation that obscured cells; immunostained cells could not be identified at the strongly curved borders of the retina. The cell distribution was homogenous and statistically nonrandom. $D$, dorsal; $R$, rostral; $V$, ventral; $C$, caudal; $o$, optic nerve fragments.

termined from labeled versus unlabeled somas in the amacrine cell and inner nuclear layers). Most of the labeled structures observed in sublayer 1 were thin, vesicle-free intervaricosity dendrites, often as small as $100 \mathrm{~nm}$ in cross section, and typically contained bundles of regularly spaced microtubules. They received only a few questionable synapses which are not recorded in Table 1. Well-oriented sections through individual varicosities typically displayed irregular groupings of vesicles, a few mitochondria, and the endings of bundles of microtubules from the intervaricosity dendrites (Figs. 16, 17). They all appeared to be of the same variety, reinforcing our previous conclusion that most of the terminals in sublayer 1 arise from a single cell type: S1 amacrine cells. Both bipolar cell and amacrine cell inputs were found on such terminals in sublayer 1. Bipolar cell inputs were also confined to sublayer 1 (Fig. 16a), although presumed S1 amacrine cell terminals were occasionally found near the terminals of type $b$ bipolar cells in sublayer 5 . The bipolar cell inputs to S1 amacrine cells were found to be from both large and small axon terminal swellings. Some, such as that depicted in Figure $16 a$, were as large as $4 \mu \mathrm{m}$ in maximum diameter, strongly supporting the identification of such terminals as type a1 bipolar cells (Ishida et al., 1980). The smaller bipolar cell processes in sublayer 1 could easily have arisen from either the frequent telodendria of type al bipolar cells (Ishida et al., 1980) or the distalmost terminal swellings of the varicose axons of blue cone selective bipolar cells (Scholes, 1975), assuming that rudd and goldfish possess similar cohorts of cone bipolar cells. Amacrine cell inputs were most often found on 

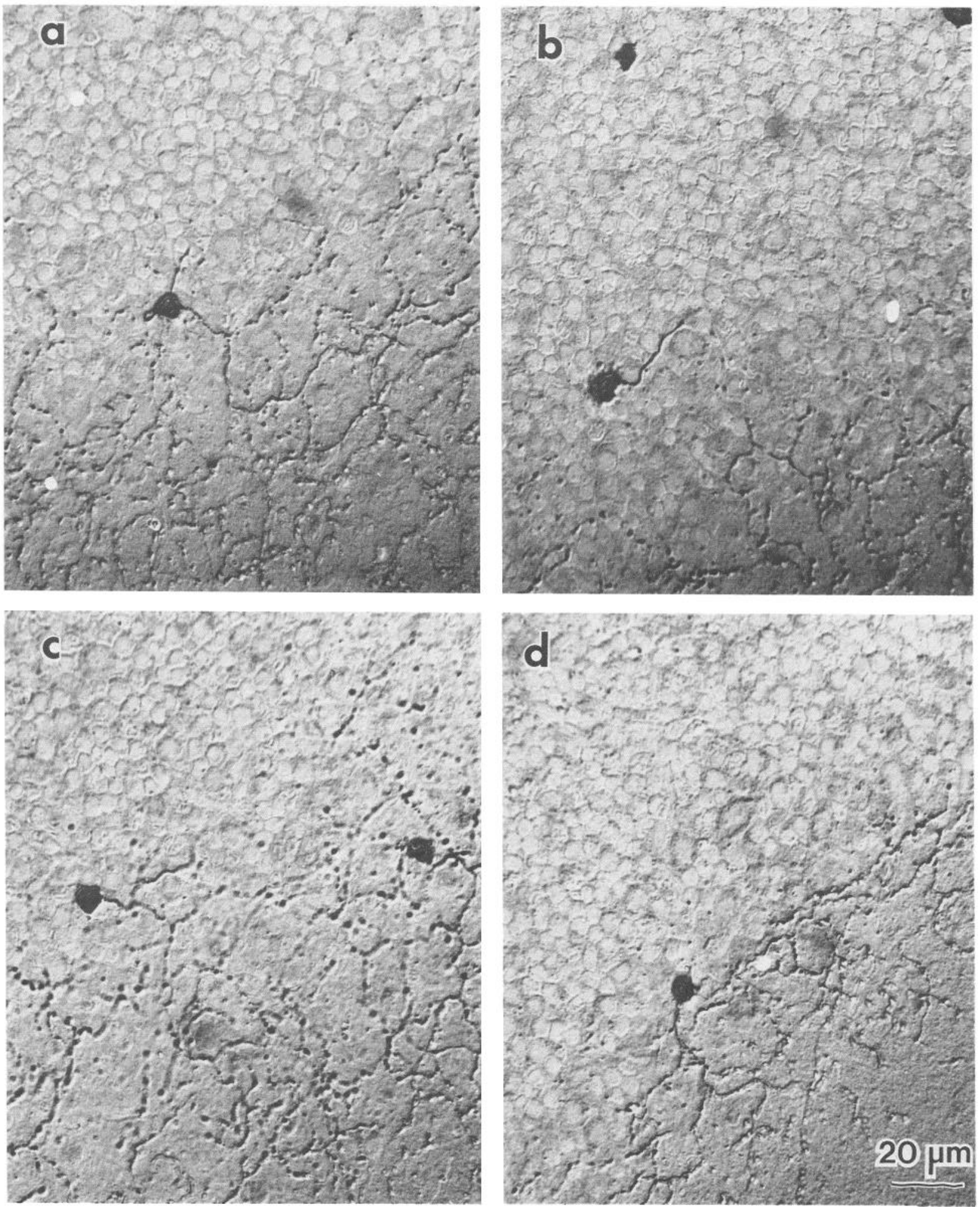

Figure 10. Oblique sections from a whole-mount goldfish retina labeled with anti-5-HT immunoglobulins. Individual S1 cells display a variety of primary dendrite trajectories. $a$, Type S1 cell initial process looping over the distal border of the soma before entering the inner plexiform layer. $b$, Primary dendrite running laterally in the amacrine cell layer for about $30 \mu \mathrm{m}$. $c$ and $d$, Dendrites that directly enter sublayer 1 .

Figure 11. Camera lucida tracing of an individual S1 amacrine cell labeled with anti-5-HT immunoglobulins in a retinal whole mount. The cell possessed a single, moderately thick primary dendrite that extended laterally from the cell for about $10 \mu \mathrm{m}$ in the amacrine cell layer and then descended to sublayer 1, where it began to thin and display varicosities. The very thinnest profiles appeared to be $0.1 \mu \mathrm{m}$ in diameter. Processes could be traced for some distance in both sublayers 1 (stippled) and 5 (solid black) before their dendrites mingled with those of other S1 cells or became too thin to reliably establish connectivity. The asterisk indicates the point at which a process in sublayer 1 spiraled down to sublayer 5 and gave off several relatively unbranched dendrites which ran for over $250 \mu \mathrm{m}$. 


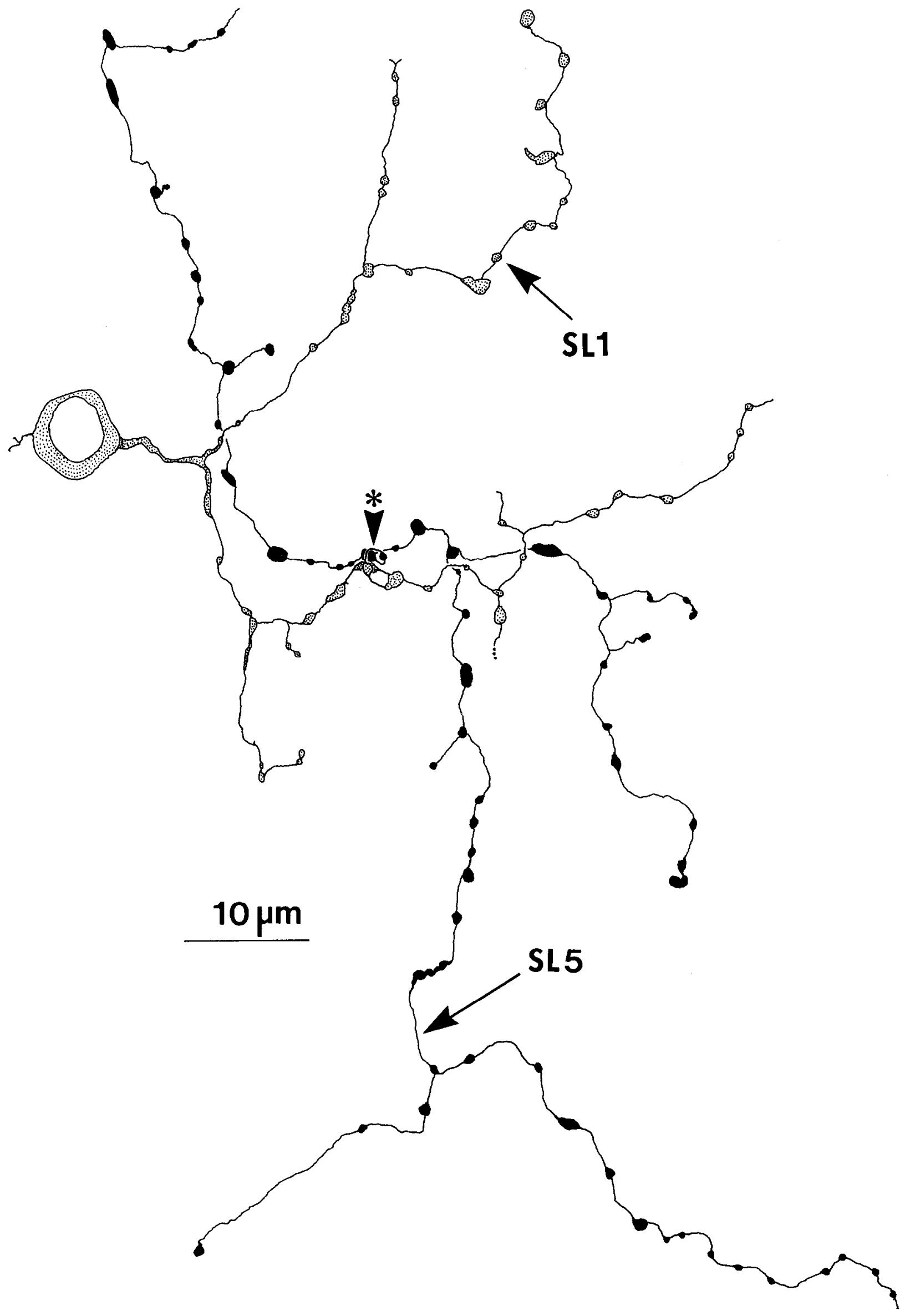



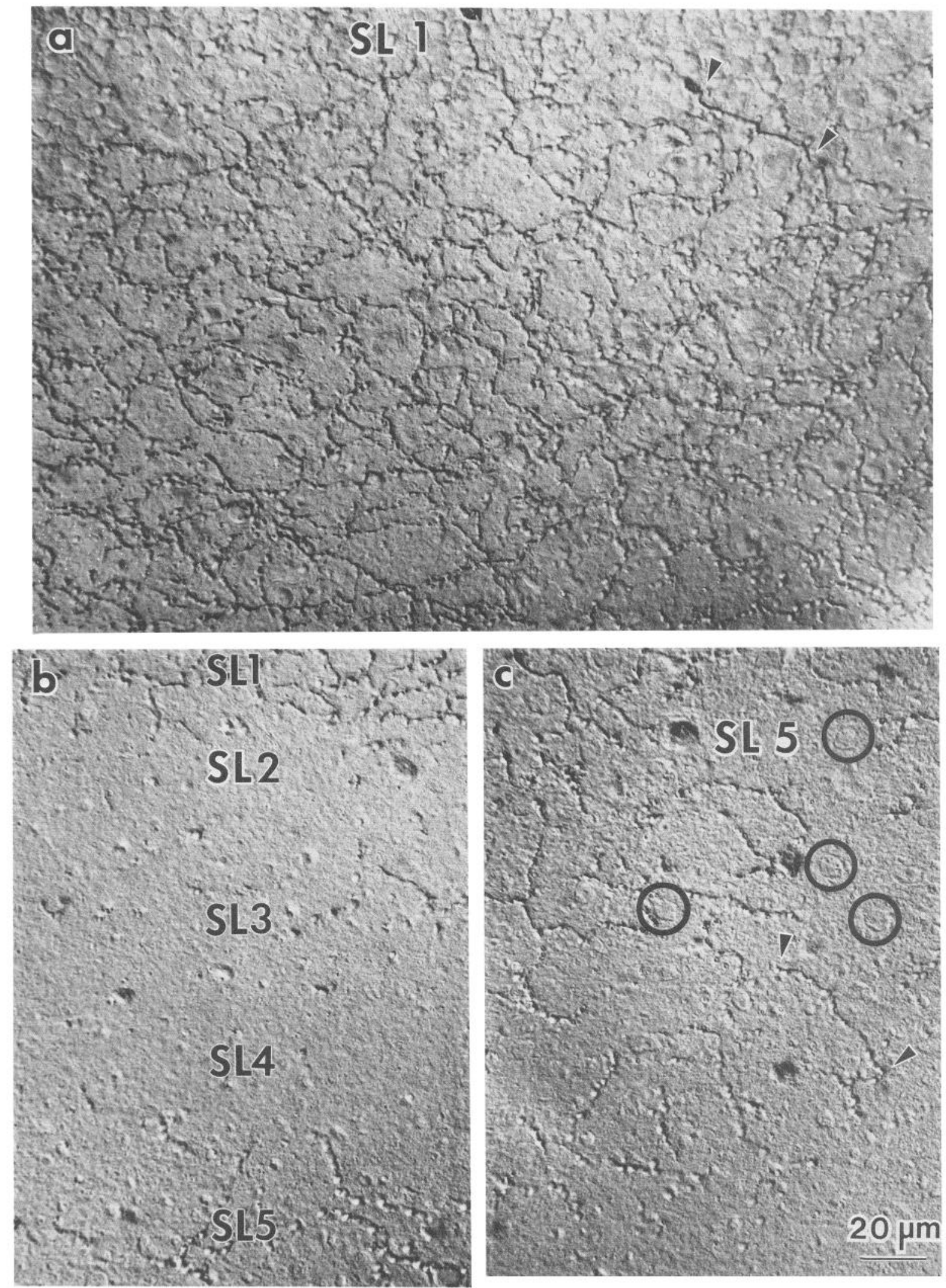

Figure 12. Horizontal and oblique $5 \mu \mathrm{m}$ sections of the inner plexiform layer from a whole-mount goldfish retina labeled with anti-5-HT immunoglobulins (Nomarski differential interference contrast). Different sublayers display characteristic variations in frequency of immunoreactive terminals. $a$, Most immunoreactive processes are found in sublayer 1, forming an irregular lacework of dendrites. Thickened initial dendritic segments can be distinguished from the more abundant varicose profiles (arrowheads). $b$, Moving proximally into sublayers $2-4$, the frequency of immunoreactive dendrites decreases significantly. The profiles in the middle inner plexiform layer are the descending processes of S1 amacrine cells. $c$, The incidence of immunoreactive dendrites increases in sublayer 5 in the form of meandering processes (arrowheads). The terminals of some unlabeled type b bipolar cells are circled. 

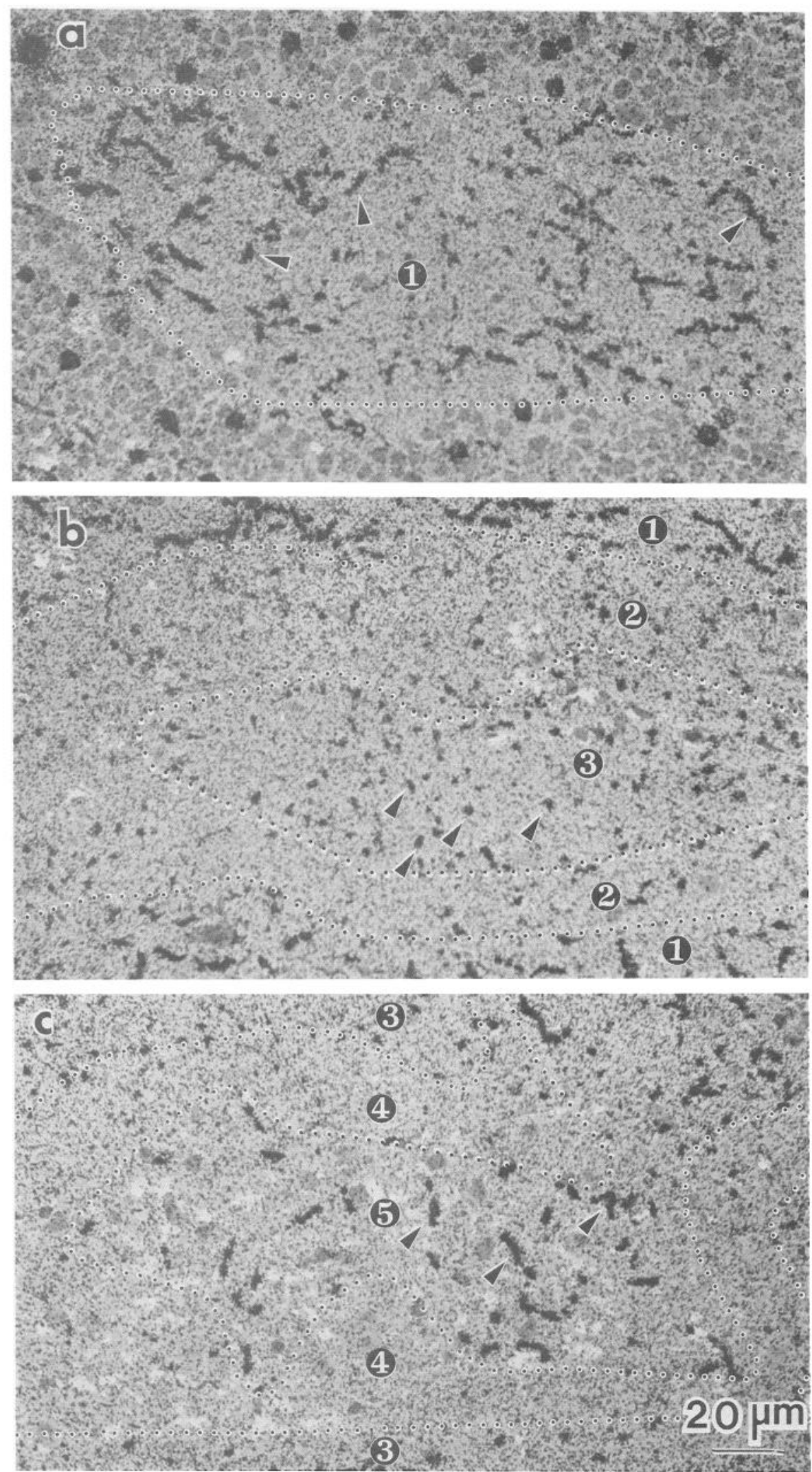

Figure 13. Series of 5 week exposure light microscope autoradiographs of horizontal-oblique $2 \mu \mathrm{m}$ sections taken through the inner plexiform layer of a ${ }^{3} \mathrm{H}-5$-HT-labeled goldfish retina. The dotted lines indicate the borders of the various layers of inner plexiform layer; the white numbers denote the sublayer. $a$, In sublayer 1 , heavily labeled, irregular dendrites presumably arising from S1 cells can be observed (arrowheads). $b$, Sublayer 3 displays, in contrast to sublayer 1 , punctate, evenly distributed, beadlike profiles (arrowheads). c, The shapes of profiles in sublayer 5 are distinctly like those of sublayer 1 and are similar in label intensity (arrowheads). the varicosities or less often on the intervaricosity dendrite very close to the terminal swelling (Fig. $16 b, c$ ). Some inputs arose from amacrine cells that were also presynaptic to the large bipolar cell terminals in sublayer 1 (Fig. 16b). Other inputs seemed to be distant from the synaptic complexes surrounding bipolar cells, and serial arrangements were sometimes observed with the S1 amacrine cell being the intermediate element (Fig. 16c). Amacrine cell inputs onto smaller ${ }^{3} \mathrm{H}-5$-HT-labeled profiles were 


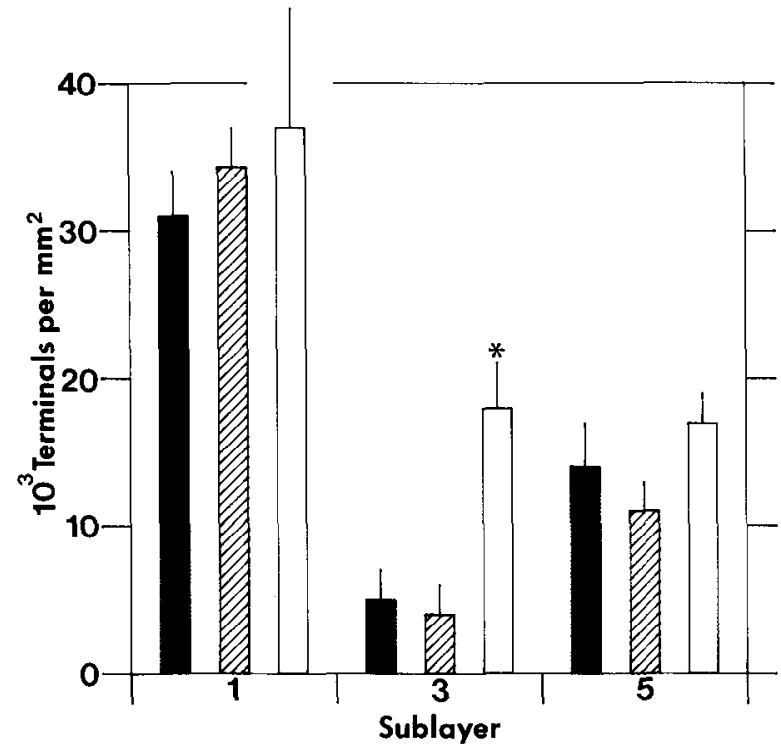

Figure 14. Terminal distribution histogram for immunocytochemistry and autoradiography. Each bar indicates the mean \pm 1 SD of the number of terminals $/ \mathrm{mm}^{2}$ for sublayers 1,3 , and 5 . Immunocytochemical counts (solid bars) were made in whole mounts by carefully focusing on the appropriate sublayers and counting all varicosities contained therein. Autoradiographic counts were made from horizontal-oblique $2 \mu \mathrm{m} \mathrm{sec}-$ tions as previously described. Short-exposurc autoradiographs ( 3 weeks) preferentially labeled S1 amacrine cells (hatched bars) and showed the same sublayer distribution as immunocytochemical measurements. Longexposure autoradiographs ( 5 weeks) displayed labeling in all 3 sublayers (see Fig. 13) and thus represented the summed terminal distributions of S1 and S2 amacrine cells (open bars). The bar marked by an asterisk in sublayer 3 is significantly different from its cohorts at $p<0.001$ (Student $t$-test).

found in sublayer 3 , but it was clearly impossible to assign the dendrites to either $\mathrm{S} 1$ or $\mathrm{S} 2$ amacrine cells.

Outputs from presumed S1 amacrine cells to bipolar cells (and vice versa) in sublayer 1 were solitary, i.e., usually a single ${ }^{3} \mathrm{H}-5$-HT-labeled process was observed near a given bipolar cell terminal (e.g., Fig. 17a). This was consistent with our observations in immunostained retinas, where we could view welldefined type al bipolar cell terminals with Nomarski optics: Only a single varicosity ever seemed to come into apposition with a given bipolar cell terminal. This accounts for the great difficulty in obtaining a large sample of well-oriented S1 amacrine cell-bipolar cell synapses by electron microscope autoradiography. In fact, well over $80 \%$ of all synaptic terminals on type al bipolar cells are labeled by uptake of ${ }^{3} \mathrm{H}-\mathrm{GABA}$ (R. E. Marc, W.-L. S. Liu, and J. F. Muller, unpublished observations). Common recipients of synapses from $\mathbf{S} 1$ amacrine cell varicosities in sublayer 1 were small $(100-250 \mathrm{~nm})$ dendrites that contained either a few vesicles (Fig. 16c) or a tight bundle of microtubules (Fig. $17 c, d$ ). Synapses from presumed S1 amacrine cells were also made onto amacrine cell-like processes in both sublayers 1 and 5 (Fig. 17e).

Sublayer 3 revealed a unique morphological class of ${ }^{3} \mathrm{H}-5$ HT-labeled terminals. Large, round varicosities up to $2.5 \mu \mathrm{m}$ in diameter were found to be well packed with mitochondria and studded with small focal synapses onto smaller nearby processes, some of which were amacrine cell-like (Fig. 17b). This distinctive rosette-like synaptology differed dramatically from anything ever observed in sublayers 1 and 5. Moreover, this class of terminals conforms identically to a second class of in- doleamine-accumulating profiles described by Holmgren-Taylor (1983) using 5,6 dihydroxytryptamine toxicity as an ultrastructural marker. Again, this differential morphology augments our terminals frequency data in support of the view that the bulk of the terminal in sublayer 3 arise from $\mathrm{S} 2$ amacrine cells. Finally, no synapses between two ${ }^{3} \mathrm{H}-5$-HT-labeled processes were ever observed.

Sublayer 2 of the inner plexiform layer was populated by numerous, large ${ }^{3} \mathrm{H}-5$-HT-labeled bipolar cell terminals up to $5 \mu \mathrm{m}$ long in the plane of the inner plexiform layer and endowed with an irregular border owing to the elaboration of telodendria. The size and location of these terminals is identical to the type a2 bipolar cells described by Ishida et al. (1980). These bipolar cells never made synapses onto or received synapses from any ${ }^{3} \mathrm{H}-5$-HT-labeled amacrine cell process.

\section{Discussion}

\section{5-HT uptake and immunoreactivity}

Teleosts are among those few vertebrates with documented elevated retinal levels of 5-HT, endogenous indoleamine-like FIF, and endogenous immunoreactivity. Together, these provide compelling evidence for a group or groups of serotonergic neurons. The data presented here argue strongly that only type S1 amacrine cells are serotonergic. Nevertheless, the differences among autoradiographic, histofluorescent, and immunocytochemical results require explanation. Such problems are not new since 5-HT uptake has long been known in the retinas of certain mammals, which, paradoxically, are notable for their paucity of endogenous 5-HT, 5-HT synthetic activity, and a lack of 5-HT immunoreactivity (Florén and Hansson, 1980; Ehinger et al., 1981; review by Osborne, 1984).

In principle, preloading FIF and ${ }^{3} \mathrm{H}-5$-HT labeling are equivalent experiments. They are both dependent on the selectivity of some transmembrane carrier systems for 5 -HT or 5-HT analogs (Ehinger and Florén, 1976; Marc, 1982; Tornqvist et al., 1983; Osborne, 1984). Thus, in cyprinid fishes, previous descriptions of indole-accumulating neurons and processes represent a blend of attributes from both $\mathrm{S} 1$ and $\mathrm{S} 2$ amacrine cells, with possible further interference from 5-HT-labeled type a2 bipolar cells. Both Ehinger and Florén (1976) and HolmgrenTaylor (1983) described indoleamine-accumulating amacrine cell somas as significantly smaller than catecholamine-accumulating cells and as displaced from the amacrine cell layer by 1 or 2 cell rows. Holmgren-Taylor (1983) also reported that there were approximately 8 times as many indoleamine-accumulating cells as dopaminergic cells. All these features are diagnostic of S2 amacrine cells. From the data presented in this paper and previous measurements on ${ }^{3} \mathrm{H}$-dopamine-accumulating neurons (Marc, 1982), we can calculate a minimum ratio for all 5-HT-accumulating versus dopamine-accumulating cells of 6:1, a reasonable match to Ilolmgren-Taylor's estimate, but one largely due to the more numerous $\mathbf{S} 2$ amacrine cells.

Descriptions of terminal stratifications in the inner plexiform layer based on FIF are also intermediate between the results with anti-5-HT immunocytochemistry and ${ }^{3} \mathrm{H}-5-\mathrm{HT}$ uptake. Indoleamine-selective FIF reveals punctate terminals in sublayers 1, 3, and 5 but apparently not sublayer 2 (Florén and Ehinger, 1976). This is consistent with the relative insensitivity of the FIF method (Osborne, 1984) and the fact that type a2 bipolar cells and their terminals display much less potent uptake than either S1 or S2 amacrine cells.

We have shown that 5-HT-accumulating amacrine cells are 

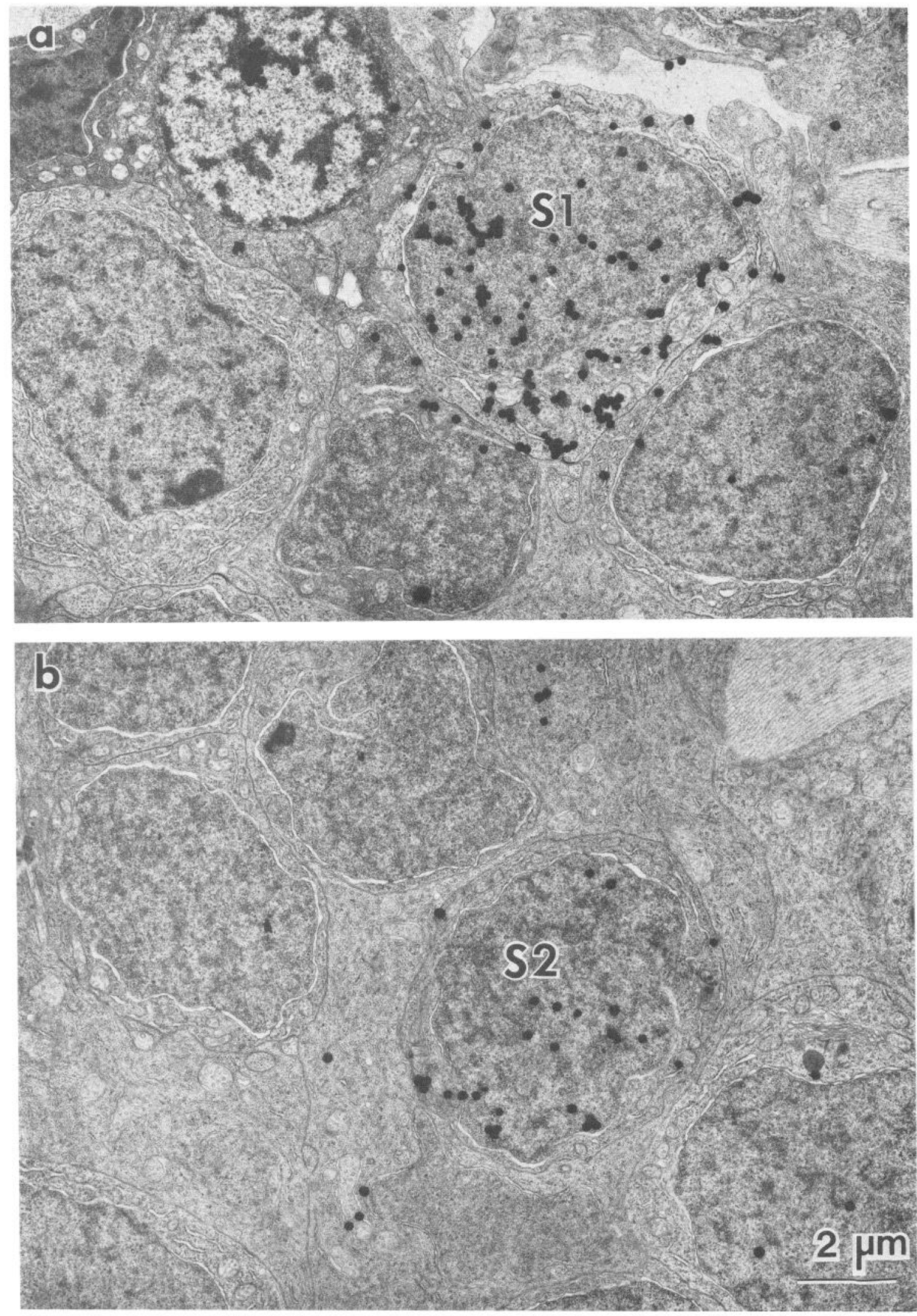

Figure 15. Electron microscope autoradiography of ${ }^{3} \mathrm{H}-5$-HT-labeled amacrine cell bodies. The differential labeling of S1 $(a)$ and S2 $(b)$ cells is quite evident. S1 cells are larger, slightly more electron lucent, with more apparent cytoplasm and nuclear flattening. 

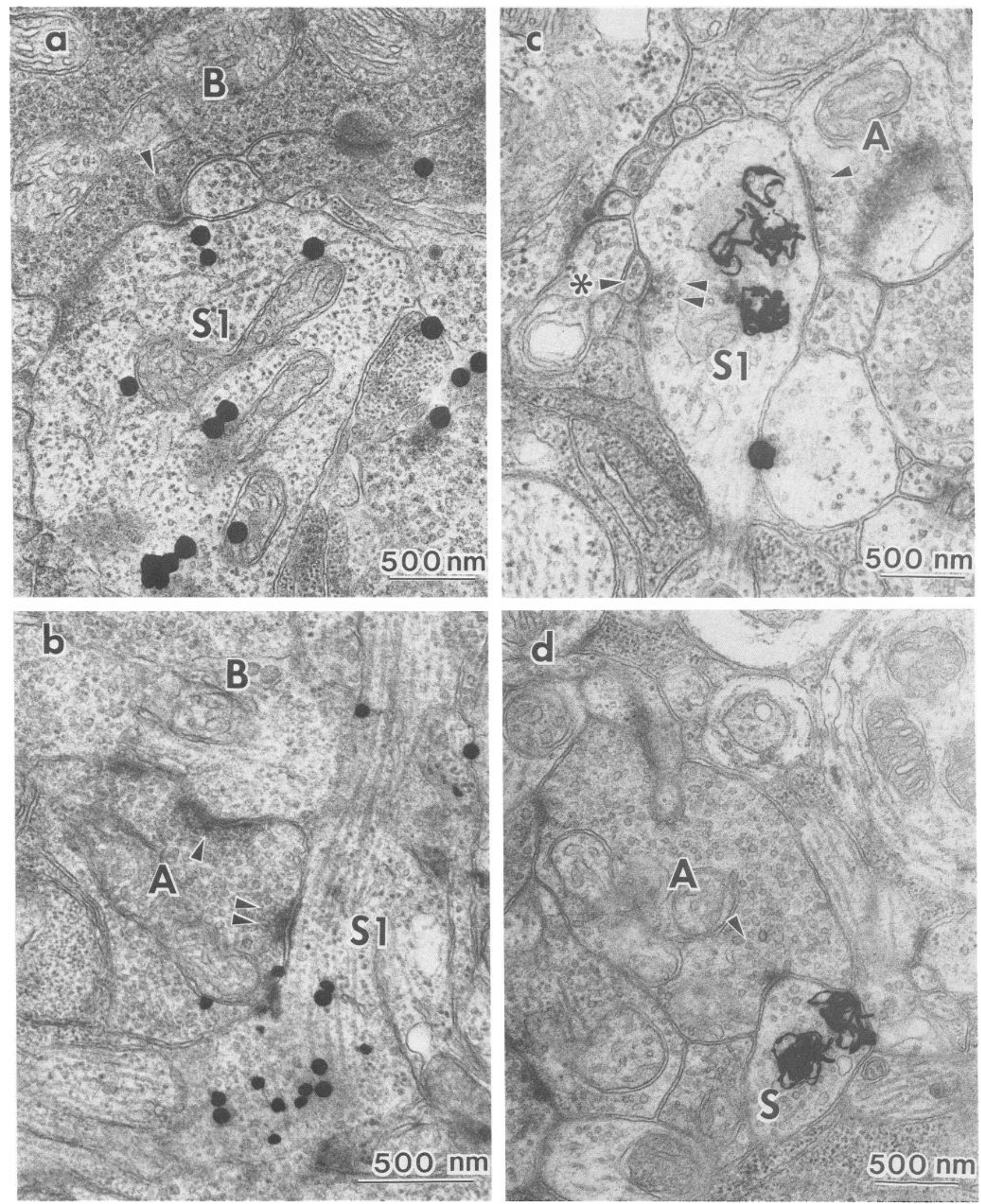

Figure 16. Inputs to ${ }^{3} \mathrm{H}-5$-HT-labeled profiles. In sublayer 1, processes presumed to arise from S1 amacrine cells receive input from ribbon and conventional synapses. $a$, Bipolar cell $(B)$ making a ribbon synapse (arrowhead) onto a heavily labeled $\mathrm{S} 1$ profile. $b$, Amacrine cell $(A)$ input onto a type S1 profile (double arrowheads) and a large bipolar cell process $(B)$ in sublayer $1 . C$, Amacrine cell $(A)$ input onto a type $\mathrm{S} 1$ profile in sublayer 1 (arrowhead). In turn, the S1 profile makes a synapse (double arrowheads) upon a small process containing a few vesicles (asterisk). $d$, Amacrine cell $(A)$ synapse (arrowhead) onto a ${ }^{3} \mathrm{H}-5$-HT-labeled process of unknown type in sublayer $3(S), a$ and $b$, phenidon development; $c$ and $d$, Kodak D-19 development. 

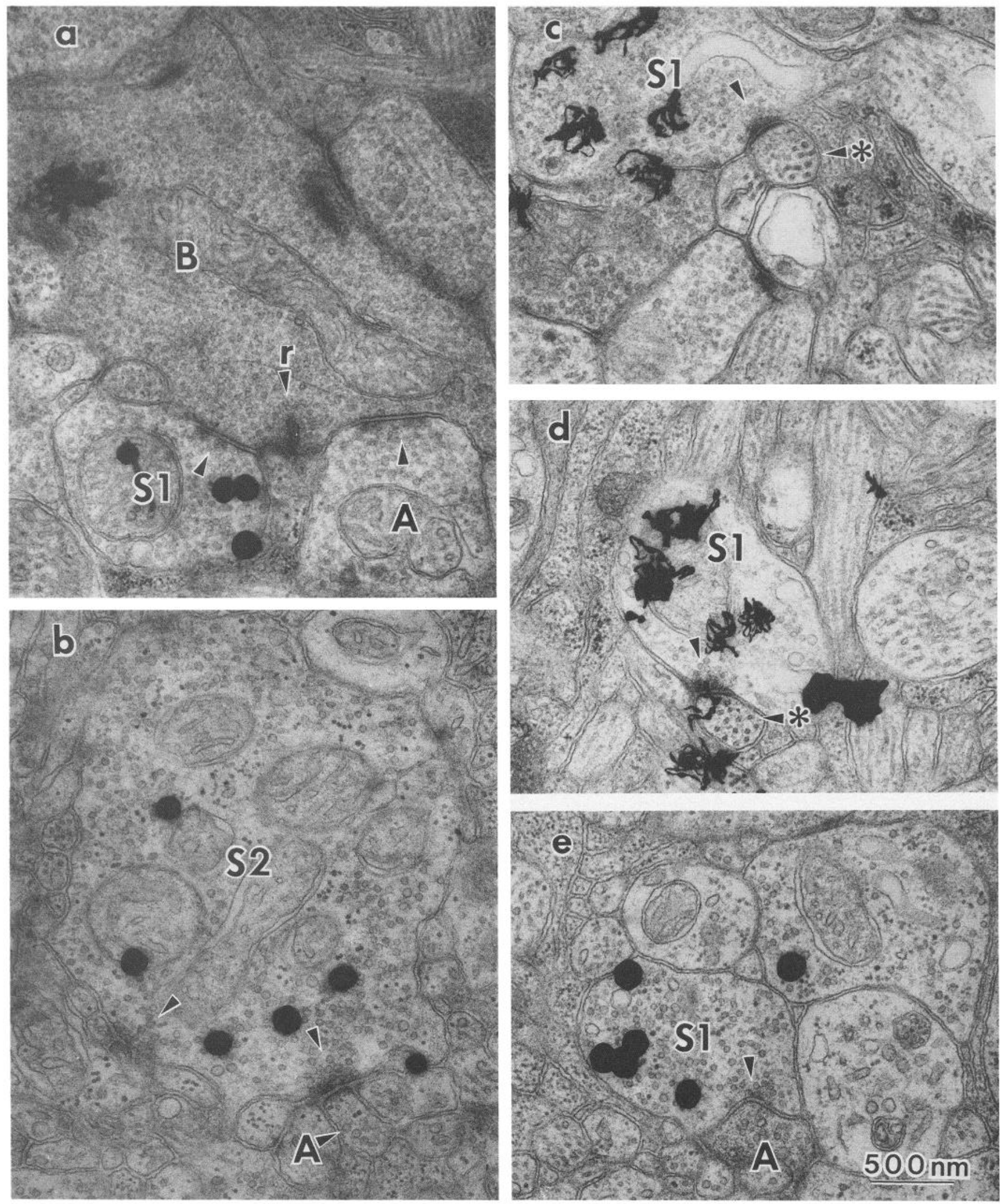

Figure 17. Outputs from ${ }^{3} \mathrm{H}-5$-HT-labeled profiles. In sublayer 1, synapses are made upon bipolar cells, amacrine cells, and some unidentified processes. $a$, Synapse from a type $\mathrm{S} 1$ profile onto a large bipolar cell terminal $(B)$ in sublayer 1 ; arrowheads indicate synapses; $r$, synaptic ribbon; $A$, unidentified amacrine cell. $b$, Large varicosity in sublayer 3 from a presumed S2 amacrine cell forming synapses (arrowheads), one of which appears to contact another type of amacrine cell $(A), c$ and $d$, Synapses (arrowheads) from type $\mathbf{S} 1$ profiles onto medium-sized dendritic branches (asterisks) containing bundles of microtubules. $e$, synapse (arrowhead) from a type S1 profile onto another type of amacrine cell $(A)$ in sublayer 5 . 

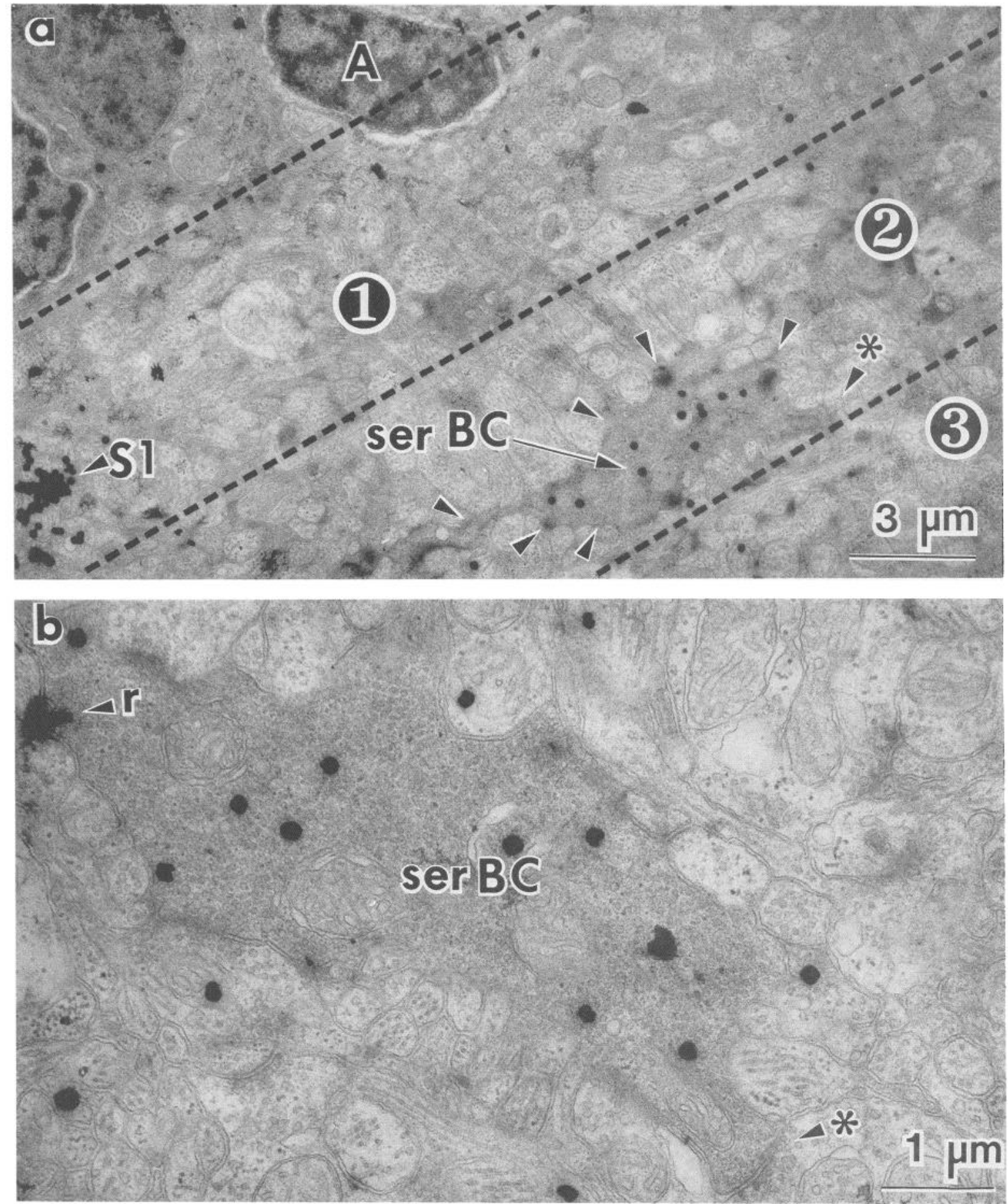

Figure 18. Labeled bipolar cell terminals in the inner plexiform layer. $a$, Low-power electron microscope autoradiograph of a ${ }^{3} \mathrm{H}-5$-HT-labeled bipolar cell terminal in sublayer 2 of the inner plexiform layer. The outline of the terminal is indicated by arrowheads. A heavily labeled type S1 terminal is located in sublayer 1 . The asterisk locates a blunt process from the labeled bipolar cell in panels $a$ and $b$. $b$, Higher-power electron microscope autoradiograph of the same terminal taken several sections later, displaying a synaptic ribbon $(r)$ and an amacrine cell input onto the blunt process (asterisk).

divisible into 2 distinctive classes, types $\mathrm{S} 1$ and $\mathrm{S} 2$, of which only type S1 amacrine cells display 5-HT immunoreactivity. Serotonin immunoreactivity has previously been described in the goldfish retina by Tornqvist et al. (1983) and Osborne (1982), and though the labeled cells were similar to type S1 amacrine cells, further morphological details were not reported. Osborne (1984) in particular noted that several vertebrate species seemed to display more 5-HT-accumulating cells than were revealed by immunocytochemistry and hypothesized that one source of the discordance could have been varying endogenous levels of 5-HT in different cell types. We examined this notion by performing immunocytochemistry with graded concentrations of antiserum and found that S2 amacrine cells never displayed any selective immunoreactivity, even at dilutions $(1: 200)$ that began to induce 


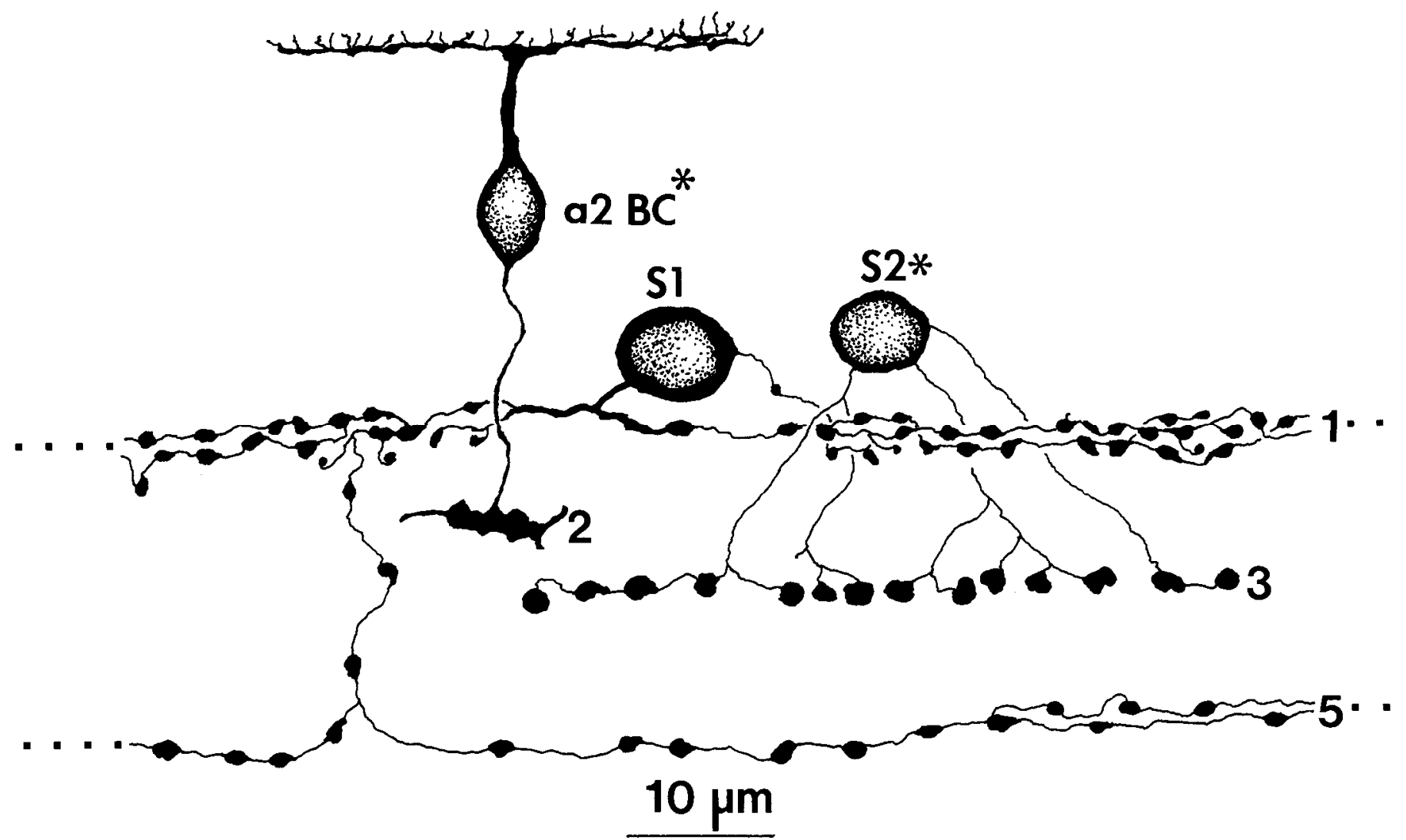

Figure 19. Scale drawing of the inferred morphologies of S1 amacrine cells, $\mathrm{S} 2$ amacrine cells and labeled bipolar cells. The drawing is based on the known morphology of type a2 bipolar cells, the reconstructed features of immunoreactive S1 amacrine cells, and the attributes of S2 cells interpreted from laminar analysis of terminal distributions (see text). It is presumed that each $\mathbf{S} 2$ cell possesses about 30 varicosities and a minimum average dendritic field diameter of $45 \mu \mathrm{m}$. The numbers at the right of each cell's terminals indicate the sublayer, and the asterisks indicate presumed nonserotonergic function.

nonspecific staining in all cell types. In our hands, S2 amacrine cells contain no more 5-HT-like material than other retinal cells. On the other hand, we did observe some selective increase in bipolar cell immunostaining in flat mounts (but not visible in vertical sections) at a serum dilution of 1:500. We will return to this point later, but it is important to acknowledge that others have observed endogenous 5-HT immunoreactivity in turtle bipolar cells (e.g., Witkovsky et al., 1984). In the goldfish, the weakness of endogenous immunoreactivity, the total absence of bipolar cell terminal staining in sublayer 2 (see Fig. 4), and the reasonable selectivity of the antiserum all argue against a significant synaptic role for 5-HT in bipolar cells.

\section{Cell types and distributions}

What can we say about the dendritic morphologies of S1 and S2 amacrine cells? First, it is evident that S1 amacrine cells account for $93-100 \%$ of the varicosities in sublayer 1 , no less than $80 \%$ of the varicosities in sublayer 5 , and probably no more than $20 \%$ in sublayer 3 . The morphologies of the ${ }^{3} \mathrm{H}-5-$ HT-labeled synaptic terminals in sublayers 1 and 5 are very similar by light and electron microscopic criteria, whereas the majority of the labeled terminals in sublayer 3 are of unique morphology (see also Holmgren-Taylor, 1983). The attribution of these separate classes of terminal stratifications to S1 or S2 amacrine cells allows some conceptual reconstitutions of their dendritic properties. Assuming a uniform partitioning of terminals among all cells in a population, each $\mathrm{S} 1$ amacrine cell should possess $\approx 331$ sublayer 1 terminals $(30,794$ terminals/ $\mathrm{mm}^{2} \div 93$ cells $/ \mathrm{mm}^{2}$ ) and $\approx 147$ sublayer 5 terminals. By the same rationale, each $\mathrm{S} 2$ amacrine cell should display an average of a mere 27 terminals/cell $\left(17,558\right.$ terminals $/ \mathrm{mm}^{2} \times 0.08$ [S2 terminal fraction] $\div 512$ cells $/ \mathrm{mm}^{2}$ ). It is also possible, based on excess terminal counts in sublayers 1 and 5 observed with long-exposure autoradiography (Table 1, Fig. 14), that each S2 cell has about 5 varicosities in both sublayers 1 and 5 . This small number falls within the experimental uncertainty of counts for immunocytochemistry and autoradiography. Furthermore, the apparent uniform distribution of terminals implies that the field of a given cell type overlaps to some degree with other members of that type.

An important advance in this area was provided by Teranishi et al. (1987), who injected several examples of a large type of indoleamine-accumulating cell (IAA) in carp with Lucifer yellow. Like S1 amacrine cells, IAA cells displayed a radiate, irregular pattern of dendrites in sublayer 1 decorated with varicosities. The carp IAA cells appeared to possess 2 or 3 primary dendrites, rather than the 1 or 2 observed for goldfish S1 amacrine cells, and there was an apparent failure to fill both the distal and proximal arbors. Even with these minor differences, it is very probable that carp large IAA cells and goldfish S1 amacrine cells are homologous.

Immunocytochemistry allows only partial dendritic field reconstruction, and we can only estimate minimum field sizes based on cell frequency. But the data from carp may allow better estimates for S1 amacrine cells. The dye-injected IAA cells averaged $510 \mu \mathrm{m}$ in diameter and, more importantly, displayed a 
mean coverage factor (mean field area $\div$ mean cell frequency) of 5.8. This means that each point in visual space intersects the dendritic domain of 5-6 IAA cells. Furthermore, this low coverage factor indicates that the dendrites of a given IAA cell reach only a little further than the somas of its nearest-neighbor IAA cells. Carp are significantly larger than goldfishes, and the rationale for extrapolating carp data requires the reasonable assumptions that (1) homologous cell types will be similarly organized in closely related species and (2) size scaling is permissible between specics. An important datum that supports thesc assumptions is the observation that small carp $(\approx 10 \mathrm{~cm}$ long) retinas exhibit about 90 IAA cells $/ \mathrm{mm}^{2}$ (Negishi et al., 1981), virtually identical to the $93 \mathrm{~S} 1$ amacrine cells $/ \mathrm{mm}^{2}$ described in this paper for large goldfish $(\approx 10 \mathrm{~cm}$ long). Furthermore, Macy and Easter (1981) demonstrated that the increase in ganglion cell receptive field center size due to growth was consistent with (though not exclusively explained by) a hypothesis "that the number of centers which overlap a given point on the retina remains approximately constant during growth." Therefore, if the coverage for $\mathrm{S} 1$ amacrine cells is also 5 or 6 , the average S1 amacrine cell dendritic arbor would be (coverage factor $\times$ cell frequency $\times[\pi / 4])^{1 / 2}$, or $\approx 260-290 \mu \mathrm{m}$. Thus, $\mathrm{S} 1$ amacrine cells have modest dendritic arbors and subtend about 100 type al bipolar cells. But if the coverage factor is truly 5-6 and, as we noted, each al bipolar cell probably receives no more than one contact, each $\mathrm{S} I$ amacrine cell would be pre- and/or postsynaptic to about 30 bipolar cells.

S2 amacrine cell somas never exhibited any autoradiographically detectable primary dendrites, unlike $S 1$ amacrine cells, whose primary dendrites are rather coarse. This means that the primary dendrites of $\mathrm{S} 2$ amacrine cells are extremely fine, perhaps similar to the intervaricosity dendrites of $\mathrm{S} 1$ amacrine cells. Assuming each $\mathrm{S} 2$ cell has a few such processes, they should descend to sublayer 3 and there support 25-30 terminals/cell, with a minimum field diameter of $\approx 44 \mu \mathrm{m}$ for a coverage factor of 1 , up to $120 \mu \mathrm{m}$ for a coverage factor of 6 (Fig. 19). No definitive Golgi-impregnated counterparts of $\mathrm{S} 1$ or $\mathrm{S} 2$ cells have been described, although there are some tempting examples. For example, a varicose amacrine cell type of sublayer 3 has been identified in the retina of a marine teleost (Boops boops, cell $3 \mathrm{MV}$; Vallerga and Deplano, 1984). This cell has roughly twice as many terminals as we might expect a type $\mathrm{S} 2$ amacrine cell to display, but it is a sparsely branching, irregular cell and may be a relative of the goldfish $\mathrm{S} 2$ amacrine cell. However, there also exist substance P-immunoreactive amacrine cells with varicose dendrites in sublayer 3 of the inner plexiform layer in the goldfish retina (Brecha et al., 1981; Yazulla et al., 1985), and little has been determined about their dendritic properties. It is quite evident, however, that the synaptic connectivity of S2 amacrine cells is wholly unlike that of substance P-immunoreactive processes in sublayer 3 , as the latter receive inputs from bipolar cells and their terminals lack the rosette arrangements of $\mathrm{S} 2$ amacrine cells.

\section{Synaptology of ${ }^{3} H-5-H T$-labeled neurons}

${ }^{3} \mathrm{H}-5-\mathrm{HT}$-labeled synaptic terminals in sublayers 1 and 5 are characteristically varicose, and most inputs and outputs occur thereon. The distributions of contact types are similar to those described by Holmgren-Taylor (1983). As argued previously, the contacts in sublayer 1 almost certainly derive exclusively from S1 amacrine cells. Within sublayer 1, S1 amacrine cells receive inputs from both bipolar cells and amacrine cells. Ob- viously, interplexiform cell synapses (Dowling and Ehinger, 1978) or possible ganglion cell synapses (Sakai et al., 1986) cannot be excluded as inputs. The bipolar cell inputs in sublayer 1 largely derive from type al bipolar cells, which are hyperpolarizing bipolar cells driven by rods and red-sensitive cones (Famiglietti et al., 1977; Stell et al., 1977; Ishida et al., 1980; Saito et al., 1984). This suggests that $S 1$ amacrine cells may respond to light stimulation with either light-onset sustained hyperpolarization or a light-offset transient depolarization. S1 amacrine cells were also presynaptic to typc a 1 bipolar ccll tcrminals, but they comprise only a minor portion of the inputs to and outputs from bipolar cell terminals. From our terminal distribution data, serial vertical section immunocytochemistry, and bipolar cell terminal distribution data (Marc, 1982), we estimate that each al bipolar cell most likely receives one $\mathrm{Sl}$ amacrine cell synapse. The bulk of all amacrine cell contacts onto type a 1 and a 2 bipolar cell terminals are GABAergic; many such GABAergic synapses are reciprocal to bipolar cells and feed forward to amacrine and ganglion cells (R. E. Marc, W.-L. S. Liu, and J. F. Muller, unpublished observations). Virtually none of the synapses are glycinergic (Marc and Lam, 1981; J. F. Muller and R. E. Marc, unpublished observations) or dopaminergic (Dowling and Ehinger, 1978). Thus, it is very likely that some of the amacrine cells that are presynaptic to both bipolar cells and S1 amacrine cells (e.g., Fig. 16b) are GABAergic. Other kinds of amacrine cell inputs to $\mathrm{S} 1$ amacrinc cclls could occur in sublaycr 1 , but we have not found any amacrine cell inputs in sublayer 5 , consistent with the observations of Holmgren-Taylor (1983). She also reported one instance of bipolar cell input in sublayer 5 , which we cannot yet affirm, though occasional ${ }^{3} \mathrm{H}-5-\mathrm{HT}$-labeled profiles were found directly apposed to bipolar cell terminals. Examination of S1 amacrine cell terminal distributions in sublayer 5 show that it is virtually impossible for every type b bipolar cell to receive a serotonergic contact. Thus, even if some depolarizing type $\mathrm{b}$ bipolar cells provide input to $\mathrm{S} 1$ amacrine cells, type al bipolar cell contacts dominate.

In addition to type al bipolar cells, some amacrine cell-like profiles and perhaps even ganglion cell dendrites receive S1 amacrine cell synapses; no synapses ever occurred between ${ }^{3} \mathrm{H}-5$ HT-labeled terminals. Considering the rarity of serotonergic synapses onto an individual bipolar cell terminal and the apparent solitary nature of other $\mathrm{S} 1$ amacrine cell synapses (they are never clustered nor do they appear to make multiple contacts), the postsynaptic effect of 5-HT may be rather potent. Serotonin has been reported to be excitatory on rat facial nucleus motoneurons(VanderMaelen and Aghajanian, 1980); facilitatory of excitation on rat spinal motoneurons (White, 1985); and both excitatory and facilitatory on cat off-center retinal ganglion cells (Thier and Wässle, 1984). Conversely, type 5-HT ${ }_{1 \mathrm{~A}}$ receptors initiate a G-protein-dependent process that increases the conductance of a potassium channel on rat hippocampal pyramidal cells, which, under normal circumstances, evokes a large hyperpolarization (Andrade et al., 1986; Colino and Halliwell, 1987). Interestingly, this 5-HT receptor complex shares a molecular final common path with $\mathrm{GABA}_{\mathrm{B}}$ receptor mechanism: Apparently, both spiperone-sensitive 5-HT receptors and baclofen-sensitive GABA receptors on hippocampal pyramidal cells act through a $\mathrm{G}$-protein to open the same potassium channel (Andrade et al., 1986). This is a provocative scenario when one considers that the known presynaptic elements at type al bipolar cells are serotonergic and GABAergic.

The synaptic contacts of $S 2$ amacrine cells were limited to 
observations of the unique, round terminals observed in sublayer 3 . In the same manner as somatic labeling, the grain densities of these large terminals in sublayer 3 were intermediate between those of the heavily labeled sublayer 1 and 5 varicosities and lightly labeled type a 2 bipolar cell terminals. We conclude that the efficacy of ${ }^{3} \mathrm{H}-5-\mathrm{HT}$ transport into $\mathrm{S} 2$ amacrine cell terminals is less than that of S1 amacrine cell terminals. Consistent with this claim, Holmgren-Taylor (1983) noted that a unique population of 5,6-dihydroxytryptamine-labeled terminals was selectively associated with sublayer 3 after treatment with higher than normal doses of the toxic amine. The new terminals were described as "much larger than the other labeled elements and appear more swollen" (compare our Fig. $17 b$ and Holmgren-Taylor's Fig. 7). Likewise, we found only amacrine cell inputs to and outputs from $\mathbf{S} 2$ amacrine cell processes. No contacts were made with bipolar cells or between labeled profiles. Obviously, we cannot make any reasonable inferences about the response properties of $\mathbf{S} 2$ amacrine cells.

The fact that ${ }^{3}$ II-5-IIT-labeled bipolar cells are abundant, have medium-small flask-shaped somas, and terminate exclusively in sublayer 2 with large, laterally oriented terminals indicates that they are type $\mathrm{a} 2$ bipolar cells which are driven by rods, red-sensitive cones, and green-sensitive cones (Ishida et al., 1980). They never contact any ${ }^{3} \mathrm{H}-5-\mathrm{HT}$-labeled processes, which further indicates that $\mathrm{S} 1$ amacrine cells are dominantly driven through type al mixed rod-red cone bipolar cells alone, and not by channels with green-sensitive cone inputs.

\section{Proposed mechanisms of labeling discordance}

Why $\mathrm{S} 2$ amacrine cells and type a2 bipolar cells display ${ }^{3} \mathrm{H}-5$ HT labeling remains unresolved. A plausible explanation for S2 amacrine cell labeling is that such cells possess a carrier for a natural ligand that also has a significant affinity for 5-HT. One would then predict that there exist compounds capable of selectivcly blocking ${ }^{3} \mathrm{H}-5-\mathrm{HT}$ labcling by $\mathrm{S} 2$ amacrine cells. Serotonin immunocytochemistry in carp has shown some weak immunoreactivity in small somas of the inner nuclear layer (Teranishi et al., 1987). The significance of this is unclear at the moment, but in our experiments we were completely unsuccessful in obtaining any 5-HT immunoreactivity in S2 amacrine cells. On similar grounds, it is possible that type a2 bipolar cells use a transmitter that is similar to 5-HT and thus possess some limited uptake capacity for 5-HT itself. We find this unlikely in the sense that fish bipolar cells seem to be excitatory to ganglion cells (Naka, 1977), and the ability of 5-HT to excite vertebrate neurons is usually due to slow and complex processes (Colino and Halliwell, 1987). Although some related indole could have fast excitatory properties, the abundance of a 2 bipolar cells further argues that such a substance should have been found by HPLC. A second possibility is that some bipolar cells may possess a form of 5-HT-selective transport associated with the synthesis of melatonin. This scenario is suggested by the observations that rat rods possess selective 5-HT uptake (Redburn and Churchill, 1987) and immunoreactivity to antisera against hydroxyindole- $O$-methyltransferase (HIOMT; Weichmann et al., 1985). One may then conclude that the 5-HT uptake of rods is permissive of melatonin synthesis. Furthermore, Weichmann and Hollyfield (1987) have demonstrated HIOMT immunoreactivity in human cone bipolar cells. Two difficulties arise with this hypothesis. First, no successful labeling of goldfish bipolar cells by anti-HIOMT serum has been achieved (Weichmann, personal communication). Second, there have been no reports of ${ }^{3} \mathrm{H}-5$-HT uptake by primate bipolar cells. There is a third hypothesis: Type a2 bipolar cells become labeled via leakage of ${ }^{3}$ II-5-IIT through gap junctions made with $\mathrm{S} 1$ amacrinc cells. We have not yet observed any gap junctions involving ${ }^{3} \mathrm{H}-$ 5-HT-labeled profiles, but many gap junctions between neuronal processes can be found in the goldfish inner plexiform layer, especially sublayers 1 and 2 (Marc et al., 1988). There is precedent for gap junctions between amacrine and bipolar cells in the mammalian retina (Famiglietti and Kolb, 1975), and these junctions have been implicated as a leakage path for ${ }^{3} \mathrm{H}$-glycine between cat type AII amacrine cells and certain cone bipolar cells (Cohen and Sterling, 1986). In our view, it is quite improbable that these bipolar cells are glycinergic, but even so, they also display some glycine-like immunoreactivity (Pourcho and Goebels, 1987). Our observations of weak nonsynaptic 5HT immunoreactivity in bipolar cells is consistent with a coupling hypothesis. The fourth possibility is that some bipolar cells are truly serotonergic but that their 5-HT content is delicately controlled, leading to difficultics in fixing it properly. Endogenous bipolar cell immunoreactivity has been observed in turtle retina, but preloading with 5-HT seems to be necessary to view it adequately (Witkovsky et al., 1984).

As yet, the arguments for all of these hypotheses rest on circumstantial evidence. It remains troublesome that indoleamine uptake has been variously attributed to rat photoreceptors (Redburn and Churchill, 1987), squirrel monkey horizontal cells (Florén and Hendrickson, 1984), some cat ganglion cells (Wässle et al., 1987), and a wide spectrum of bipolar and amacrine cells in many species. In most of these cases there is either an absence of or negating evidence regarding additional markers for serotonergic function. We propose S1 amacrine cells to be the sole serotonergic neurons of the goldfish retina because of the concordant localization of 5-HT uptake and 5-HT immunoreactivity. Though the neurochemical meaning of additional sites of 5-HT uptake remains problematic, ${ }^{3} \mathrm{H}-5-\mathrm{HT}$ labeling of $\mathrm{S} 2$ amacrine cells and type a 2 bipolar cells still constitutes a potent means to selectively mark them and further investigate their participation in retinal circuitry.

\section{References}

Andrade, R., R. C. Malenka, and R. A. Nicoll (1986) A G protein couples serotonin and $\mathrm{GABA}_{\mathrm{B}}$ receptors to the same channels in hippocampus. Science 234: 1261-1265.

Boutielle, M. (1976) The "LIGOP" method for routine ultrastructural autoradiography: A combination of single grid coating, gold intensification and phenidon development. J. Microse. Biol. Cell 27: 121128.

Bras, H., G. Chazal, J. Destombes, and J. J. Puizillout (1986) Anti5-hydroxytryptamine antibodies: Studies on their cross-reactivity in vitro and their immunohistochemical specificity. Exp. Brain Res. 63: 627-638.

Brecha, N., S. C. Sharma, and H. J. Karten (1981) Localization of substance P-like immunoreactivity in the adult and developing goldfish retina. Neuroscience 6: 2737-2746.

Cohen, E., and P. Sterling (1986) Accumulation of ${ }^{3} \mathrm{H}$-glycine by cone bipolar neurons in the cat retina. J. Comp. Neurol. 250: 1-7.

Colino, A., and J. V. Halliwell (1987) Differential modulation of three separate K-conductances in hippocampal CAI neurons by serotonin. Nature 328: 73-77

Conzolazione, A., C. Milstein, B. Wright, and A. C. Cuello (1982) Immunocytochemical detection of serotonin with monoclonal antibodies. J. Histochem. Cytochem. 29: 1425-1430.

Dowling, J. E., and B. Ehinger (1978) The interplexiform cell system. I. Synapses of the dopaminergic neurons of the goldfish retina. Proc. R. Soc. London [Biol.] 201: 7-26. 
Ehinger, B., and I. Florén (1976) Indoleamine accumulating neurons in the retina of rabbit, cat and goldfish. Cell Tissue Res. 175: 37-48

Ehinger, B., C. Hansson, and K. Tornqvist (1981) 5-Hydroxytryptamine in the retina of some mammals. Exp. Eye Res. 33: 663-672.

Famiglietti, E. V., Jr., and H. Kolb (1975) A bistratified amacrine cell and synaptic circuitry of the inner plexiform layer of the retina. Brain Res. 84: 293-300.

Famiglietti, E. V., Jr., M. Tachibana, and A. Kaneko (1977) Neuronal architecture of $\mathrm{ON}$ and OFF pathways to ganglion cells in the carp retina. Science 198: 1267-1268.

Florén, I., and H. Ch. Hansson (1980) Investigations into whether 5 -hydroxytryptamine is a neurotransmitter in the retina of rabbit and chicken. Invest. Ophthalmol. Vis. Sci. 19: 117-125.

Florén, I., and A. Hendrickson (1984) Indoleamine-accumulating horizontal cells in the squirrel monkey retina. Invest. Ophthalmol. Vis. Sci. 25: 997-1006.

Holmgren-Taylor, I. (1983) Synaptic organization of the indoleamineaccumulating neurons in the cyprinid retina. Cell Tissue Res. 229: $317-335$

Ishida, A. T., W. K. Stell, and D. O. Lightfoot (1980) Rod and cone inputs to bipolar cells in goldfish retina. J. Comp. Neurol. 191: 315335 .

Macy, A., and S. S. Easter Jr. (1981) Growth-related changes in the size of receptive field centers of retina ganglion cells in goldfish. Vision Res. 10: 1497-1504.

Marc, R. E. (1982) The spatial organization of ncurochcmically classified interneurons in the goldfish retina. I. Local patterns. Vision Res. 22: 589-608.

Marc, R. E. (1986) Neurochemical stratification in the inner plexiform layer of the vertebrate retina. Vision Res. 26: 223-238.

Marc, R. E., and D. M. K. Lam (1981) Glycinergic pathways in the goldfish retina. J. Neurosci. $1:$ 152-165.

Marc, R. E., and W.-L. S. Liu (1985) Glycine-accumulating neurons of the human retina. J. Comp. Neurol. 232: 241-260.

Marc, R. E., W. K. Stell, D. Bok, and D. M. K. Lam (1978) GABAergic pathways in the goldfish retina. J. Comp. Neurol. 182: 221-246.

Marc, R. F., W.-L. S. Liu, and J. F. Muller (1988) Gap junctions in the inner plexiform layer of the goldfish retina. Vision Res. 28: 9-24.

Matute, C., and P. Streit (1986) Monoclonal antibodies demonstrating GABA-like immunoreactivity. Histochemistry 86: 147-157.

Naka, K.-I. (1977) Functional organization of the catfish retina. J. Neurophysiol. 40: 26-43.

Negishi, K., T. Teranishi, and S. Kato (1981) Density of retinal dopaminergic cells and indoleamine-accumulating cells in different-sized carp. Acta Histochem. Cytochem. 14: 654-660.

Negishi, K., S. Kato, and T. Teranishi (1983) Development of retinal monoamine neurotransmitters in larval goldfish: A histofluorescence study. Dev. Brain Res. 312: 111-116.

Osborne, N. N. (1982) Evidence for serotonin being a neurotransmitter in the retina. In Biology of Serotonergic Transmission, N. N. Osborne, ed., pp. 401-430, Wiley, Chichester, IK.

Osborne, N. N. (1984) Indoleamines in the eye with special reference to the serotonergic neurones of the retina. In Progress in Retinal Research, N. N. Osborne and G. Chader, eds., Vol. 3, pp. 61-103, Pergamon, Oxford, UK.

Ostle, B., and R. W. Mensing (1975) Statistics in Research, Iowa State University Press, Ames, IA.

Pourcho, R., and D. J. Goebel (1987) Visualization of endogenous glycine in the cat retina: An immunocytochemical study with Fab fragments. J. Neurosci. 7: 1 189-1 197.

Redburn, D. A., and L. Churchill (1987) An indoleamine system in photoreceptor cell terminals of the Long-Evans rat retina. J. Neurosci. 7: 319-329.

Saito, T., T. Kujiraoka, and J.-I. Toyoda (1984) Electrical and morphological properties of off-center bipolar cells in the carp retina. $J$ Comp. Neurol. 222: 200-208.

Sakai, H., K.-I. Naka, and J. E. Dowling (1986) Ganglion cell dendrites are pre-synaptic in catfish retina. Nature 319: 495-497.
Sandell, J. H., and R. H. Masland (1986) A system of indoleamineaccumulating neurons in the rabbit retina. J. Neurosci. 6:3331-3347.

Scholes, J. (1975) Colour receptors and their synaptic connexions, in the retina of a cyprinid fish. Phil. Trans. R. Soc. London [Biol.] 270: $61-118$.

Steinbusch, H. W. M., A. A. J. Verhofstad, and H. W. J. Joosten (1978) Localization of serotonin in the central nervous system by immunohistochemistry: Description of a specific and sensitive technique and some applications. Neuroscience 3: 811-819.

Stell, W. K., and D. O. Lightfoot (1975) Color-specific interconnections of cones and cone horizontal cells in the retina of the goldfish. J. Comp. Ncurol. 159: 473-502.

Stell, W. K., A. T. Ishida, and D. O. Lightfoot (1977) Structural basis for on- and off-center responses in retinal bipolar cells. Science 198: 1269-1271.

Sternberger, L. A., P. H. Hardy Jr., J. J. Cuculis, and H. G. Meyer (1970) The unlabeled antibody-enzyme method of immunohistochemistry. Preparation and properties of soluble antigen-antibody complex (horseradish peroxidase-antihorseradish peroxidase) and its use in identification of spirochetes. J. Histochem. Cytochem. 18:315333.

Teranishi, T., K. Negishi, S. Hidaka, and K.-I. Naka (1987) Dendritic morphology of indoleamine cells revealed by intracellular injection of Lucifer Yellow in fixed carp retina. Neuroscience 22: 323-329.

Thier, P., and H. Wässle (1984) Indoleamine-mediated reciprocal modulation of on-centre and off-centre ganglion cell activity in the retina of the cat. J. Physiol. (Lond.) 351: 613-630.

Tornqvist, K., C. Hansson, and B. Ehinger (1983) Immunohistochemical and quantitative analysis of 5-hydroxytryptamine in the retina of some vertebrates. Neurochem. Int. 5: 299-308.

Vallerga, S., and S. Deplano (1984) Differentiation, extent and layering of amacrine cell dendrites in the retina of a sparid fish. Proc. R. Soc. London [Biol.] 221: 465-477.

VanderMaelen, C. P., and G. K. Aghajanian (1980) Intracellular studies showing modulation of facial motoneurone excitability by serotonin. Nature 287: 346-347.

Vaney, D. I. (1986) Morphological identification of serotonin-accumulating neurons in the living retina. Science 233: 444-446.

Wässle, H., T. Voigt, and B. Patel (1987) Morphological and immunocytochcmical identification of indoleamine-accumulating neurons in the cat retina. J. Neurosci. 7: 1574-1585.

Weichmann, A. F., and J. G. Hollyfield (1987) Localization of hydroxyindole- $O$-methyltransferase-like immunoreactivity in photoreceptors and cone bipolar cells in the human retina: $A$ light and electron microscope study. J. Comp. Neurol. 258: 253-266.

Weichmann, A. F., D. Bok, and J. Horowitz (1985) Localization of hydroxyindole- $O$-methyltransferase in the mammalian pineal gland and retina. Invest. Ophthalmol. Vis. Sci. 26: 253-265.

Weiler, R., and J. Ammermüller (1986) Immunocytochemical localization of serotonin in intracellularly analyzed and dye-injected ganglion cells of the turtle retina. Neurosci. Lett. 72: 147-152.

Weiler, R., and M. Schütte (1985a) Morphological and pharmacological analysis of putative serotonergic bipolar and amacrine cells in the retina of a turtlc, Pseudemys scripta elegans. Cell Tissue Res. 241: 373-382.

Weiler, R., and M. Schütte (1985b) Kainic-acid induced release of serotonin from OFF-bipolar cells in the turtle retina. Brain Res. 360: 379-383.

White, S. R. (1985) Serotonin and co-localized peptides: Effects on spinal motoneuron excitability. Peptides $6: 123-127$.

Witkovsky, P., W. Eldred, and H. J. Karten (1984) Catecholamineand indoleamine-containing neurons in the turtle retina. J. Comp. Neurol. 228: 217-225.

Yazulla, S., K. M. Studholme, and C. L. Zucker (1985) Synaptic organization of substance P-like immunoreactive amacrine cells in goldfish retina. J. Comp. Neurol. 231: 232-238. 